\title{
Effects of Alcoholic Extracts of Bangladeshi Mangrove Acanthus ilicifolius Linn. (Acanthaceae) Leaf and Stem on Atherogenic Model of Wistar Albino Rats
}

\author{
Rubaba Karim $\left(\mathbb{D},{ }^{1}\right.$ Mst Marium Begum $\mathbb{D}^{1},{ }^{2}$ Md. Abdul Alim, ${ }^{3,4}$ Md. Sahab Uddin $\left(\mathbb{D},{ }^{5,6}\right.$ \\ Md. Tanvir Kabir $\mathbb{D}^{0},{ }^{7}$ Ashfia Fatima Khan, ${ }^{1}$ Tanjina Islam, ${ }^{1}$ Shafiul Islam Khan, \\ and Md. Sohanur Rahman ${ }^{8}{ }^{8}$ \\ ${ }^{1}$ Department of Pharmacy, Primeasia University, Dhaka 1213, Bangladesh \\ ${ }^{2}$ Department of Pharmacy, East West University, Dhaka, Bangladesh \\ ${ }^{3}$ Department of Chemistry, Bangabandhu Sheikh Mujibur Rahman Science and Technology University, Gopalganj, Bangladesh \\ ${ }^{4}$ Graduate School of Innovative Life Science, Faculty of Engineering, University of Toyama, Toyama, Japan \\ ${ }^{5}$ Department of Pharmacy, Southeast University, Dhaka, Bangladesh \\ ${ }^{6}$ Pharmakon Neuroscience Research Network, Dhaka, Bangladesh \\ ${ }^{7}$ Department of Pharmacy, Brac University, Dhaka 1212, Bangladesh \\ ${ }^{8}$ Department of Biochemistry and Molecular Biology, Trust University, Barishal, Ruiya, Nobogram Road, \\ Barishal 8200, Bangladesh
}

Correspondence should be addressed to Rubaba Karim; rubkam.85@gmail.com and

Md. Sohanur Rahman; sohanbmb.ru@gmail.com

Received 17 July 2020; Revised 13 April 2021; Accepted 10 May 2021; Published 31 May 2021

Academic Editor: Maria Grazia Ferraro

Copyright (C) 2021 Rubaba Karim et al. This is an open access article distributed under the Creative Commons Attribution License, which permits unrestricted use, distribution, and reproduction in any medium, provided the original work is properly cited.

\begin{abstract}
Acanthus ilicifolius Linn. (Acanthaceae) is a popular mangrove ethnomedicinal plant that cures several ailments, including asthma, diabetes, cancer, and many others. Our experiment was aimed at evaluating the anti-atherogenic effect of A. ilicifolius (leaf and stem) on a high-fat diet-induced atherogenic rat model. Atherosclerosis was developed in 12 weeks. Treatment with the standard drug (3 mg/kg b.w./day, p.o. of Simvastatin), separate doses of methanolic and ethanolic extracts of A. ilicifolius leaf (250 and $500 \mathrm{mg} / \mathrm{kg}$ b.w./day, p.o.), and stem (200 and $400 \mathrm{mg} / \mathrm{kg}$ b.w./day, p.o.) was subsequently conducted for additional 15 days. The anti-atherogenic effect was evaluated by estimating the change in body weight, systolic blood pressure, and lipid profile. Histopathology of aorta, liver, and kidney of atherogenic models was done for further evaluation. The antioxidant effect of different extracts was performed via DPPH (2,2-diphenyl-1-picrylhydrazyl) assay using ascorbic acid as standard. The anticoagulant effect was determined after 15 days of treatment with the same doses of the plant extracts and the standard Warfarin ( $2 \mathrm{mg} / \mathrm{kg}$ b.w./day, p.o.). When compared with atherogenic control, treatment with A. ilicifolius significantly reduced $(p<0.01)$ body weight, systolic blood pressure, and serum lipid levels while it elevated HDL (high-density lipoprotein) level in a dose-dependent manner. Moreover, bleeding and clotting time was significantly decreased $(p<0.01)$ under the treatment of plant extracts. The histopathological data showed considerable improvement in tissue morphology after treatment. Our study evidenced that the alcoholic extracts of A. ilicifolius leaf and stem have antiatherogenic properties and may be recommended as a potential herbal remedy for preventing cardiovascular diseases.
\end{abstract}

\section{Introduction}

Mangrove plants are considered promising sources of phytochemical constituents that are immensely used in ethnopharmaceutical practices worldwide [1]. The secondary metabolites produced by these plants have been proved to possess certain medicinal values. Health practitioners of many developing countries traditionally employ them to cure a wide variety of ailments since ancient times [2,3]. A. ilicifolius, which is indigenously identified as "Hargoza," is one of the wellknown mangrove plants in India, and other tropical areas of Asia, Africa, and northern Australia. In Bangladesh, this plant 
is wide-spectrum available in large areas of mangrove forest in Sunderbans and the coastal regions of southern districts [4]. A. ilicifolius possesses many pharmacological activities, including anti-inflammatory, antioxidant, anti-cancer $[5,6]$, hepatoprotective, anti-ulcer, anti-osteoporotic [7], antileishmanial, and antimicrobial activities [3, 8], for which it has been used in traditional Indian (Ayurveda) as well as Chinese medicine for many years [3, 9].

Atherosclerosis has markedly gained global attention for decades. It is an inflammatory disease involving several factors that generate lipid deposition in the arterial walls leading to arterial lesions. These factors are considerably total cholesterol, low-density lipoprotein cholesterol, triglycerides, insulin resistance, inflammation, reactive oxygen species or free radicals, and diet containing a large amount of saturated fat [10-16]. Diets rich in lipids have been often applied to develop an atherogenic model using mice or related rodents [16]. Hence, atherogenic animal model could be a promising kit to perceive pathology of the disease and assess the consequence of the treatment pattern.

According to an earlier report, methanolic extract of A. ilicifolius exhibited anti-inflammatory activity against rat paw edema [3]. Another investigation indicated that the plant confirmed the anti-diabetic effect in rats and lowered blood glucose levels similar to the standard hypoglycemic drug (glibenclamide) [17]. Leaves and flower extracts of the plant displayed significant antioxidant properties in the past studies $[18,19]$. However, the stem extract of $A$. ilicifolius demonstrated potential absorption of free radicals that corresponded to ascorbic acid action [20]. Aqueous extract of roots of this plant exhibited potent anticoagulant and anti-cancer activities in the recent past year [21].

Many phenolic compounds, mainly phenolic acids and phenolic glycosides [22-25], were found in various parts of A. ilicifolius that associated with potent antioxidant, anticancer, anti-atherosclerotic, antibacterial, antiviral, and antiinflammatory activities [26-29]. The plant also possessed other significant bioactive compounds, including flavonoids, lignans, phenyl ethanols, and triterpenoids [3], which functioned as antioxidants and were responsible for free radical scavenging properties [30-32].

Concerning the above facts and features about A. ilicifolius, the current work aimed to investigate the presence of primary phytoconstituents, the anti-atherosclerotic, and anticoagulant properties of alcoholic extracts of leaves and stem of Bangladeshi mangrove variety of this plant using high-fat diet-induced atherosclerosis in rats. The study further continued to determine antioxidant activities of this plant in order to scientifically support its utilization as a traditional medicine against cardiac diseases.

\section{Materials and Methods}

2.1. Drugs, Chemicals, and Nutritional Supplements. Warfarin, Simvastatin, and ascorbic acid were obtained from Eskayef Bangladesh Limited. DPPH (2, 2-diphenyl-1picrylhydrazyl) and cholesterol were obtained from Sigma Aldrich Chemicals, Germany. Soybean oil and corn starch were purchased from the local market (Unilever food,
Bangladesh). The minerals and vitamins for the animal diet were obtained from Merck (Darmstadt, Germany). Lipid profile and blood coagulation test kits (for Activated Partial Thromboplastin Time and Prothrombin Time assays) were procured from Sigma Aldrich Chemicals, Germany. The rest of the chemicals and reagents were purchased from Merck (Darmstadt, Germany), and all were analytical grade chemicals.

2.2. Collection and Authentication of Plant. Fresh plant parts (leaves and stems) were collected from St. Martin Island, Bangladesh, in October 2018. The plant parts were identified and certified by a taxonomist of Bangladesh National Herbarium, Dhaka, Bangladesh. A voucher specimen with the accession number DACB 46483 was deposited for further acknowledgment.

2.3. Extraction of Plant Parts. The leaves and stem were washed and then shaded dried for consecutive 5 days. The dried leaves and stems were subjected separately to a mechanical grinder to prepare coarse powder. 200 gm of coarse powder of leaves and stems was stored in separate air-tight containers and kept in a dry, cool, and dark place until used for the experiment. The crude extract was prepared by following the previous method with a slight modification [33]. The extraction was done by maceration process using $95 \%, 400 \mathrm{~mL}$ of methanol and ethanol as solvents into which $200 \mathrm{gm}$ of dried powder of leaves and stems soaked separately. The mixtures were kept for 21 days within $22-25^{\circ} \mathrm{C}$ with infrequent shaking. Later, Whatman filter paper No. 1 was used to filter the extracts, followed by concentrating the filtrates using a rotary evaporator at $45^{\circ} \mathrm{C}$ (pressure $57 \mathrm{mmHg}$ ). The samples were kept unlidded for some days to volatilize the residual solvents. Finally, the residues of methanolic and ethanolic extracts of leaves and stems were collected separately, and the mass of each extract was calculated in percentage according to the following equation:

$$
\text { yield }(\%)=\frac{\text { mass of crude extract } \times 100}{\text { total mass of dry powder }} \text {. }
$$

The percentage extraction of AILE and AILM was found to be $15 \%$ and $23 \%$, respectively, while AISM and AISE were observed to be $17 \%$ and $20 \%$.

2.4. Screening of Biologically Active Compounds. Freshly prepared extracts were subjected to preliminary phytochemical analysis to identify secondary metabolites like carbohydrates, triterpenoids, alkaloids, glycosides, tannins, flavonoids, and essential oils. Phytochemical tests using standard protocols [33-35] were performed to construct the presence of bioactive compounds in different extracts of A. ilicifolius.

2.5. Quantitative Analysis of In Vitro Antioxidant Activity. The free radical scavenging properties of different extracts of A. ilicifolius were determined against DPPH (2,2-diphenyl-1picrylhydrazyl) by using the previous method with slight 
modification [36] where ascorbic acid was considered as the standard. The $\mathrm{IC}_{50}$ (50\% inhibitory concentration) values of the DPPH assay were determined by a linear regression curve of $\%$ inhibition versus sample concentration. Different concentrations of ascorbic acid and plant extracts (1.25, 2.5, $5,10,50$, and $100 \mu \mathrm{g} / \mathrm{mL}$ ) have been prepared. $100 \mu \mathrm{L}$ from each concentration was mixed with $200 \mu \mathrm{L}$ of $0.2 \mathrm{mM}$ DPPH solution in $1 \%$ methanol. The suspension left incubated for half an hour in dark condition, and the absorbance was measured at $517 \mathrm{~nm}$ using a UV double beam spectra scan. The blank contained the same amount of DPPH solution. The absorbance of all samples was recorded at every 5 minutes interval. This experiment was carried out in triplicates, and the antioxidant activity of extracts was calculated by using the following formula:

$$
\text { free radical scavenging activity }(\%)=\frac{\text { absorbance of control }- \text { absorbance of sample }}{\text { absorbance of control }} \times 100
$$

2.6. Experimental Animals. 72 male Wistar albino rats aged between 8 and 9 weeks have been purchased from the Pharmacy Department of Jahangirnagar University (Dhaka, Bangladesh). The animals weighed between $110 \mathrm{gm}$ and $120 \mathrm{gm}$ and were sorted into 12 groups in separate polypropylene cages where each cage contained 6 rats. They were accommodated under temperature $\left(25 \pm 2^{\circ} \mathrm{C}\right)$ and humiditycontrolled zone to maintain an adequate light-dark cycle (12:12 hours). There was a consistent supply of water and diet ad libitum to all animals, and they were allowed to acclimatize for ten days before the experiment. Rats of each group underwent euthanasia during all surgical procedures, and anesthesia was conducted by supplying isoflurane (5\% in $100 \%$ oxygen). Humanitarian care was taken throughout the experiments as per the guidelines demonstrated in the Guide for the Care and Use of Laboratory Animals (NIH publication No: 85-23, revised in 1985). All protocols were authorized by the Biomedical Research Center, University of Dhaka, Bangladesh (Reference No: BMRC/EC/2016-17/98) before commencing the experiments.

2.7. Development of the Atherogenic Model. The nutritional composition is vitally recognized to be associated with dysmetabolic diseases like obesity, diabetes, and cardiovascular diseases [37]. Moreover, consumption of a highsaturated fat diet by humans results in an immense risk of developing diabetes and heart disease [38-40]. Application of a high-fat diet (HFD), consisting of saturated fat, and cholesterol, in the rodent model, reported elevating lipid levels [41, 42]. According to the earlier pathological evidence, hyperlipidemia is the chief precondition for the development of atherosclerosis leading to cardiovascular disability and death [43]. The present experiment recruited a previously established high-fat diet composition with a slight modification to develop the atherogenic rat model (Table 1) [44]. All ingredients of the diet were separately stored at $4^{\circ} \mathrm{C}$. Atherosclerosis was induced by feeding HFD to the animals for 12 weeks. Freshly prepared pellets were fed daily. The initial and final body weight of all animals were recorded by digital weighing balance. Standard laboratory animal feed for the normal control group of animals has been purchased from the Pharmacy Department of Jahangirnagar University (Dhaka, Bangladesh), which consisted of 5\% ash, 23\% crude protein, $10 \%$ crude fibre, $7 \%$ fat, $50 \%$ carbohydrate, $0.6 \%$ vitamins, and minerals and the remaining is water $(4.4 \%)$. The atherogenic rat model development was assessed by estimating the change in body weight, total serum lipid content, systolic blood pressure, atherogenic index, and analyzing histopathology of rat aorta.

2.8. Treatment Protocol. After 12 weeks of consumption of HFD, different doses of methanolic and ethanolic extracts of A. ilicifolius leaf and stem were administered to the animals for 15 consecutive days [45]. All extracts and standard drugs (Simvastatin and Warfarin) were diluted in 2\% Tween 80 and administered orally ( $5 \mathrm{~mL} / \mathrm{kg}$ of body weight, p.o.) to animals with the help of oral intubation. In order to evaluate the anti-atherosclerotic/anti-atherogenic, antioxidant, antihypertensive, and anticoagulative properties of the plant extracts, standard doses of alcoholic extracts of the leaf (250 and $500 \mathrm{mg} / \mathrm{kg}$, b.w.) [46] and stem (200 mg/kg of b.w. and $400 \mathrm{mg} / \mathrm{kg}$ of b.w.) [47] have been selected based on the previous report with a little modification and also from the observation of acute toxicity study on animals using different doses (as mentioned below). Selected doses were dispensed to different groups of experimental rats. Rats were allocated into 12 groups and subsequently received treatments, as shown in Table 2.

2.9. Acute Toxicity Study. Acute oral toxicity study was performed to ensure the safety of selected doses, based upon the previous report with slight modification [45], by following a standard protocol stated in the organization of economic cooperation and development (OECD) guidelines 423. Total 15 healthy rats were allocated into 5 groups, where each group contained 3 rats. Animals were weighed and fasted overnight prior to the administration of various plant extracts at doses of 300, 400, 500 600, and $700 \mathrm{mg} / \mathrm{kg}$ b.w., p.o. and observed at every 30 minutes interval for 24 hours of each dosing for 14 days. Any physical signs of toxicity like pain, palpitation, reduced respiration, or mortality were noted for each animal.

2.10. Estimation of Systolic Blood Pressure. After 15 days of treatment, systolic blood pressure of conscious rats was measured in a $30^{\circ} \mathrm{C}$ environment by the tail-cuff method using BP Monitor Mk-1030, Mouromachi Kikaj Co. Ltd., at 
TABle 1: Diet (HFD) composition (g/1000 g of diet) (Matos et al. [44]).

\begin{tabular}{|c|c|c|c|c|c|c|c|c|}
\hline Ingredients & Cellulose & Corn starch & Soybean oil & Casein & Choline & Cholesterol & Salts* & Vitamins $^{* *}$ \\
\hline Amount incorporated in the diet $(\mathrm{g} / \mathrm{kg})$ & 132.00 & 429.00 & 260.00 & 110.00 & 1.00 & 15.00 & 45.00 & 8.00 \\
\hline Total calories (Kcal) & & & & 4538. & & & & \\
\hline
\end{tabular}

Salts* (g/kg of HFD): incorporation of $\mathrm{MnSO}_{4} . \mathrm{H}_{2} \mathrm{O}-4, \mathrm{ZnSO} 4.7 \mathrm{H}_{2} \mathrm{O}-0.55, \mathrm{FeSO}_{4} .7 \mathrm{H}_{2} \mathrm{O}-27.3, \mathrm{KH}_{2} \mathrm{PO}_{4}-390, \mathrm{CoCl}_{2} .6 \mathrm{H}_{2} \mathrm{O}-0.03, \mathrm{CuSO}_{4} .5 \mathrm{H}_{2} \mathrm{O}-0.48$, KI-0.80 and NaCl-139 in standard HFD. Vitamins** (g/kg of HFD): incorporation of vitamin A-2,100,000 IU, Vitamin D ${ }_{3}-210,000$ IU, PABA-8.00, myoInositol-9.00, Vitamin $B_{3}-3.00$, Vitamin $B_{5}-3.00$, Vitamin $B_{2}-0.90$, Vitamin $B_{1}-0.40$, Vitamin $B_{6}-0.50$, Vitamin $B_{9}-0.20$, Vitamin $B_{7}-0.04$, Cyanocobalamin 0.003, Choline-250.0, Vitamin E-10,000 IU, and Sucrose q.s.p. 1200 in standard HFD.

the Phytochemical Laboratory of Dhaka University, Bangladesh. An average of three measurements per rat was recorded. Animals were allowed to acclimatize for normal blood circulation in the tail by placing them in the holder for 10 to 15 minutes before taking readings [48].

2.11. Blood Sample Collection. At the end of the experiment, $5 \mathrm{~mL}$ of blood samples of rats from each group was collected after an overnight fast by retro-orbital puncture under general anesthesia. Centrifugation was done at $3000 \mathrm{rpm}$ for 10 minutes at $4^{\circ} \mathrm{C}$ in order to separate serum, and the samples were preserved at $-80^{\circ} \mathrm{C}$ for future analysis.

2.12. Analysis of Lipid Profile. The serum levels of total cholesterol (TC), triglyceride (TG), and high-density lipoprotein cholesterol (HDL-C) were determined by using previously established protocols [49-51]. The Friedewald formula [52] has been used to calculate serum low-density lipoprotein cholesterol (LDL-C $=$ TC-HDL-C-TG/5). The atherogenic index was estimated using the equation given below [53]: atherogenic index $=\log 10$ (TG/HDL-C).

2.13. Determination of Anticoagulant Activity. The plant extracts' anticoagulant properties were performed to further add value to the usage of $A$. ilicifolius as a potential source of the herb against heart diseases since synthetic blood thinners like Warfarin are often prescribed for the treatment of atherosclerosis.

2.14. APTT and PT Assays Ex Vivo. The ex vivo assays were carried out after treatment with crude extracts for 15 days. For animals from each group $(n=6)$, including normal control and standard, blood was collected after 120 minutes of the last serving dose [54]. Both APTT (activated partial thromboplastin time) and PT (prothrombin time) assays were performed by using commercially available reagent kits and following previously established methods using Warfarin ( $2 \mathrm{mg} / \mathrm{kg}$ body weight, p.o.) as a standard drug $[55,56]$.

2.15. In Vivo Clotting Time Assay. Blood samples of rats were subjected to measurement of whole blood clotting time after the treatment using the capillary glass tube method [57]. Samples were collected 90 minutes after the last dose via retro-orbital plexus using a capillary glass tube, which was placed on a glass-slide to permit coagulation [55]. Following this, a dry needle was used to agitate the blood every 30 seconds, and this was continued until the needle wire aroused a fibrous protein representing the clotting time [58].

2.16. In Vivo Bleeding Time Assay. In vivo assay of bleeding time was estimated in rats after 90 minutes of administration of the final dose. Each rat's tail was marked and cut at $5 \mathrm{~mm}$ long and subsequently submerged in saline water at $37^{\circ} \mathrm{C}$. An intervening time between the cutting tail tip and bleeding was recorded as bleeding time [59].

2.17. Histopathology. Rat aorta, liver, and kidney were subjected to histopathological examinations at the end of the experiment. These organs were excised and submerged into freshly prepared fixative solution (10\% formalin) for 48 hours at $37^{\circ} \mathrm{C}$. Cross-sections of paraffin-embedded aorta, liver, and kidney with $5 \mu \mathrm{m}$ thickness were exposed to hematoxylin and eosin staining. The tissue assessment was executed in Exim Bank Hospital, Department of histopathology, Dhaka, Bangladesh.

2.18. Statistical Analysis. Data of the present work were represented as mean \pm SEM (standard error mean) $(n=6)$. The experimental values of treatment and normal control groups were compared against the atherogenic model by applying one-way analysis of variance (ANOVA) subsequent to Dunnett's test where $p<0.05$ was expressed as a 95\% level of statistical significance. Graphpad Instat version 3.10 was used for statistical analysis.

\section{Results}

3.1. Qualitative Phytochemical Analysis. The preliminary phytochemical screening process revealed that both leaf and stem of the plant extracts contain significant phytochemical constituents, including alkaloids, flavonoids, phenol, glycosides, steroids, terpenoids, and saponins, as represented in Table 3.

3.2. Analysis of the Antioxidant Activity of Plant. The DPPH assay determined the percentage of antiradical efficiency of leaf and stem extracts of $A$. ilicifolius as summarized in Table 4 . The IC50 values of the assay are presented in Table 5. The data were compared with standard ascorbic acid. An exponential increase in antioxidant activities with increased concentration of the plant extracts was observed. Maximum inhibition of DPPH free radical was found in AILM $(76.45 \pm 0.24 \%$ at $100 \mu \mathrm{g} / \mathrm{mL})$, showing the lowest $\mathrm{IC}_{50}$ value $(5.89 \mu \mathrm{g} / \mathrm{mL})$. Significant differences were noted $(p<0.01)$ in 


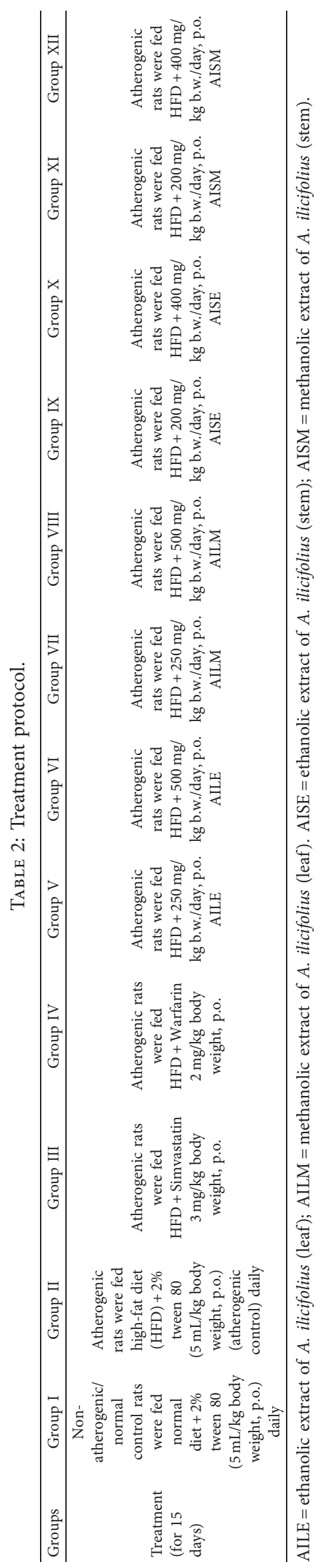


TABLe 3: Qualitative phytochemical analysis of the ethanolic and methanolic extracts of A. ilicifolius (leaf and stem).

\begin{tabular}{lcccc}
\hline Phytoconstituents & AILE & AILM & AISE & \\
\hline Alkaloids & + & + & + & + \\
Flavonoids & + & + & + & + \\
Phenols & + & + & + & + \\
Glycosides & + & + & + & + \\
Steroids & + & + & + & + \\
Terpenoids & + & + & + & + \\
Carbohydrates & + & + & + \\
Saponins & + & + & + \\
\hline
\end{tabular}

$+=$ present, $=$ absent. AILE $=$ ethanolic extract of A. ilicifolius (leaf); AILM = methanolic extract of A. ilicifolius (leaf). AISE = ethanolic extract of A. ilicifolius (stem); AISM = methanolic extract of A. ilicifolius (stem).

Table 4: DPPH-based antioxidant effect of alcoholic extracts of A. ilicifolius (leaf and stem) against standard ascorbic acid.

\begin{tabular}{|c|c|c|c|c|c|}
\hline \multirow{2}{*}{ Concentration $(\mu \mathrm{g} / \mathrm{mL})$} & \multicolumn{5}{|c|}{ Mean \% inhibition of DPPH free radical } \\
\hline & Ascorbic acid (standard) & AILM & AILE & AISE & AISM \\
\hline 1.25 & $44.50 \pm 0.41$ & $39.03 \pm 0.41^{* *}$ & $26.18 \pm 0.44^{* *}$ & $31.60 \pm 0.55^{* *}$ & $24.30 \pm 0.42^{* *}$ \\
\hline 2.5 & $48.25 \pm 0.39$ & $40.90 \pm 0.37^{* *}$ & $42.01 \pm 0.41^{* *}$ & $37.30 \pm 0.44^{* *}$ & $28.30 \pm 0.40^{* *}$ \\
\hline 5 & $51.88 \pm 0.18$ & $42.30 \pm 0.33^{* *}$ & $51.88 \pm 0.43^{* *}$ & $45.60 \pm 0.67^{* *}$ & $29.10 \pm 0.45^{* *}$ \\
\hline 10 & $61.43 \pm 0.33$ & $56.20 \pm 0.31^{* *}$ & $56.03 \pm 0.32^{* *}$ & $62.30 \pm 0.43^{\eta}$ & $47.10 \pm 0.45^{* *}$ \\
\hline 50 & $71.50 \pm 0.22$ & $73.27 \pm 0.24^{* *}$ & $73.19 \pm 0.44^{* *}$ & $68.30 \pm 0.35^{* *}$ & $66.20 \pm 0.48^{* *}$ \\
\hline 100 & $91.45 \pm 0.26$ & $76.45 \pm 0.24^{* *}$ & $74.58 \pm 0.39^{* *}$ & $72.60 \pm 0.58^{* *}$ & $73.50 \pm 0.38^{* *}$ \\
\hline
\end{tabular}

AILE = ethanolic extract of A. ilicifolius (leaf); AILM=methanolic extract of A. ilicifolius (leaf). AISE= ethanolic extract of A. ilicifolius (stem); AISM $=$ methanolic extract of $A$. ilicifolius (stem).

TABLE 5: $\mathrm{IC}_{50}$ values and regression equations of DPPH assay for different test extracts.

\begin{tabular}{lccr}
\hline Sample & $\mathrm{IC}_{50}(\mu \mathrm{g} / \mathrm{mL})$ & Regression equation & $R^{2}$ \\
\hline AILM & 5.89 & $y=22.141 x+32.92$ & 0.956 \\
AILE & 6.59 & $y=24.302 x+30.098$ & 0.948 \\
AISE & 7.10 & $y=22.27 x+31.051$ & 0.931 \\
AISM & 14.80 & $y=27.921 x+17.295$ & 0.963 \\
Ascorbic acid & 3.03 & $y=22.954 x+38.93$ & 0.932 \\
\hline
\end{tabular}

AILE = ethanolic extract of A. ilicifolius (leaf); AILM=methanolic extract of A. ilicifolius (leaf); AISE = ethanolic extract of A. ilicifolius (stem); $\mathrm{AISM}=$ methanolic extract of $A$. ilicifolius (stem). $\mathrm{IC}_{50}=$ inhibitory concentration $50, y=$ dependent variable (\% inhibition), i.e., $50 \%, x=$ independent variable (logarithmic concentration), $R^{2}=$ coefficient of determination representing how close the data (dependent and independent variables) are to the fitted regression line; a value close to $100 \%$ (1.00) is recognized as best fitted line (linear relationship between dependent and independent variables).

case of both leaf and stem extracts when compared with ascorbic acid. However, AISE exhibited a result $(62.30 \pm 0.43 \%)$ that corresponds to ascorbic acid data at $10 \mu \mathrm{g} / \mathrm{mL}$.

3.3. Acute Toxicity Test. After administering different doses (300, 400, 500, 600, and $700 \mathrm{mg} / \mathrm{kg}$ b.w., p.o.) of plant extracts for two weeks, no behavioral abnormality, physical change, or mortality was observed in rats. Moreover, no toxic reaction was observed at any given dose until the end of the experiment. As a result, the doses 250 and $500 \mathrm{mg} / \mathrm{kg}$ b.w./day (p.o.) of alcoholic extracts of leaf and 200 and $400 \mathrm{mg} / \mathrm{kg}$ b.w./day (p.o.) of the stem of A. ilicifolius were selected as safe doses to carry out further pharmacological investigations for the present work.

3.4. Changes in Body Weight. The mean body weight $(n=6)$ of rats reduced after treatment with the extracts for 15 days. The changes in mean body weight of rats have been represented in percentage as given in Table 6 . Around $65 \%$ of body weight was gained by the animals that consumed a high-fat diet for 12 weeks. The maximum percentage of bodyweight reduction was observed in rats administered $250 \mathrm{mg} / \mathrm{kg}$ b.w., p.o. (13.33\%) of AILM and $400 \mathrm{mg} / \mathrm{kg}$ bw, p.o. (12.17\%) of AISM at the end of week 14 (Table 6).

3.5. Evaluation of Systolic Blood Pressure. Treatment with alcoholic extracts of $A$. ilicifolius (leaf and stem) after 15 days significantly decreased $(p<0.01)$ systolic blood pressure of rats when compared with the atherogenic model (Group II) (Figure 1). Consumption of high-fat diet by the experimental animals caused elevated blood pressure $(195.5 \pm 0.46 \mathrm{mmHg})$. The systolic blood pressure reduced maximum when treated with $500 \mathrm{mg} / \mathrm{kg}$ b.w. (p.o.) of AILM $(121.25 \pm 0.32 \mathrm{mmHg})$ that corresponded to normal level $(120.5 \pm 0.46 \mathrm{mmHg})$. Administration of Simvastatin ( $3 \mathrm{mg} / \mathrm{kg}$ b.w., p.o.) also reduced the systolic blood pressure in animals $(120.25 \pm 0.32 \mathrm{mmHg})$ to the normal level. 
TABLE 6: Measurement of changes in mean body weight of rats $(n=6)$.

\begin{tabular}{|c|c|c|c|c|c|}
\hline \multirow[b]{2}{*}{ Groups } & \multirow[b]{2}{*}{ Treatment } & \multicolumn{4}{|c|}{ Mean body weight $(\mathrm{g})$} \\
\hline & & Initial body weight & Body weight (week 12) & Body weight (week 14) & $\begin{array}{c}\text { Change in body weight after } \\
\text { treatment }(\%)\end{array}$ \\
\hline Group I & Normal diet & 120 & 180 & - & - \\
\hline Group II & High-fat diet (HFD) & 115 & 327 & - & - \\
\hline Group III & $\begin{array}{c}\text { Simvastatin } 3 \mathrm{mg} / \mathrm{kg} \\
\text { b.w./p.o. }\end{array}$ & 120 & 323 & 298 & 7.8 \\
\hline Group V & $\begin{array}{c}\mathrm{HFD}+\text { AILE } 250 \mathrm{mg} / \mathrm{kg} \\
\text { bw/p.o. }\end{array}$ & 110 & 300 & 287 & 4.34 \\
\hline Group VI & $\begin{array}{c}\mathrm{HFD}+\text { AILE } 500 \mathrm{mg} / \mathrm{kg} \\
\text { b.w./p.o. }\end{array}$ & 110 & 330 & 291 & 11.9 \\
\hline $\begin{array}{l}\text { Group } \\
\text { VII }\end{array}$ & $\begin{array}{c}\mathrm{HFD}+\text { AILM } 250 \mathrm{mg} / \mathrm{kg} \\
\text { b.w./p.o. }\end{array}$ & 110 & 330 & 286 & 13.33 \\
\hline $\begin{array}{l}\text { Group } \\
\text { VIII }\end{array}$ & $\begin{array}{c}\mathrm{HFD}+\text { AILM } 500 \mathrm{mg} / \mathrm{kg} \\
\text { b.w./p.o. }\end{array}$ & 120 & 312 & 289 & 7.38 \\
\hline Group IX & $\begin{array}{c}\text { HFD + AISE } 200 \mathrm{mg} / \mathrm{kg} \\
\text { b.w./p.o. }\end{array}$ & 120 & 320 & 286 & 10.63 \\
\hline Group X & $\begin{array}{c}\mathrm{HFD}+\text { AISE } 400 \mathrm{mg} / \mathrm{kg} \\
\text { b.w./p.o. }\end{array}$ & 110 & 310 & 290 & 6.45 \\
\hline Group XI & $\begin{array}{c}\mathrm{HFD}+\text { AISM } 200 \mathrm{mg} / \mathrm{kg} \\
\text { b.w./p.o. }\end{array}$ & 110 & 300 & 285 & 5.00 \\
\hline $\begin{array}{l}\text { Group } \\
\text { XII }\end{array}$ & $\begin{array}{c}\text { HFD + AISM } 400 \mathrm{mg} / \mathrm{kg} \\
\text { b.w./p.o. }\end{array}$ & 115 & 330 & 288 & 12.73 \\
\hline
\end{tabular}

AILE = ethanolic extract of A. ilicifolius (leaf), AILM=methanolic extract of A. ilicifolius (leaf). AISE = ethanolic extract of A. ilicifolius (stem), AISM = methanolic extract of $A$. ilicifolius (stem).

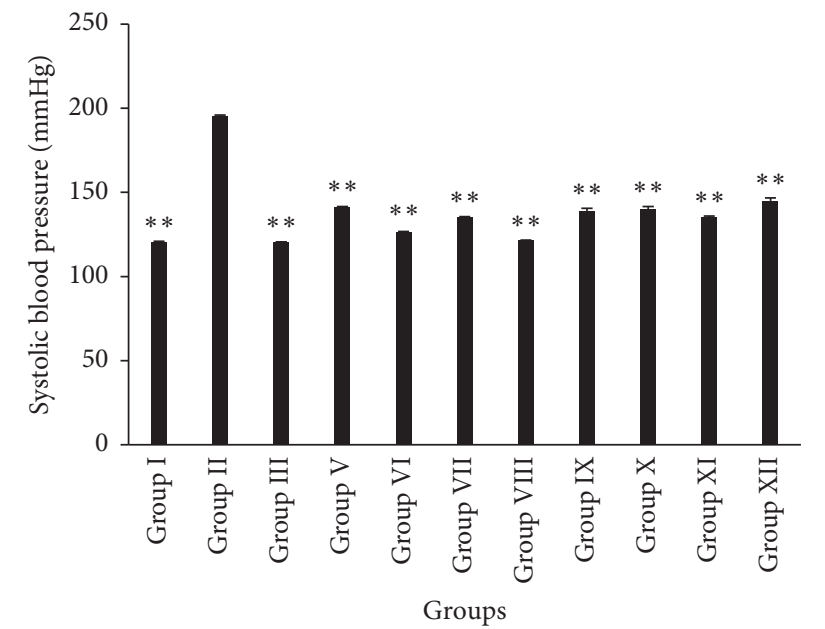

FIGURE 1: Estimation of systolic blood pressure of rats at the end of the treatment. Results were expressed in mean \pm SEM $(n=6)$. $\left({ }^{*}\right)$ indicates statistically significant difference from HFD group using ANOVA, followed by Dunnett's multiple comparison test $\left({ }^{*} p<0.05\right.$, ** $p<0.01$ ) where treatment groups were compared with Group II (atherogenic control). Group I = normal control, Group II = Atherogenic control (HFD), Group III = atherogenic control $+3 \mathrm{mg} / \mathrm{kg}$ of Simvastatin, Group V = atherogenic control $+250 \mathrm{mg} / \mathrm{kg}$ ethanolic extract of A. ilicifolius (leaf), Group VI= atherogenic control $+500 \mathrm{mg} / \mathrm{kg}$ ethanolic extract of A. ilicifolius (leaf), Group VII = atherogenic control $+250 \mathrm{mg} / \mathrm{kg}$ methanolic extract of A. ilicifolius (leaf), Group VIII = atherogenic control $+500 \mathrm{mg} / \mathrm{kg}$ methanolic extract of A. ilicifolius (leaf), Group IX = atherogenic control $+200 \mathrm{mg} / \mathrm{kg}$ methanolic extract of A. ilicifolius (stem), Group X=atherogenic control $+400 \mathrm{mg} / \mathrm{kg}$ methanolic extract of A. ilicifolius (stem), Group XI = atherogenic control $+200 \mathrm{mg} / \mathrm{kg}$ ethanolic extract of A. ilicifolius (stem), Group $\mathrm{XII}=$ atherogenic control $+400 \mathrm{mg} / \mathrm{kg}$ ethanolic extract of $A$. ilicifolius (stem).

3.6. Assessment of Lipid Profile. The effect of the plant extracts on the lipid profile of the experimental animals is demonstrated in Figure 2. The levels of serum TC, TG, and LDL-C significantly reduced $(p<0.01)$ while HDL-C significantly escalated $(p<0.01)$ at the end of treatment with alcoholic leaf and stem extracts of $A$. ilicifolius when compared against the atherogenic control group. The serum TC, TG, and LDL-C markedly elevated in high-fat diet-fed rats $\quad(194.95 \pm 0.39 \mathrm{mg} / \mathrm{dL} ; \quad 222.15 \pm 0.43 \mathrm{mg} / \mathrm{dL} \quad$ and $150.33 \pm 0.32)$. In contrast, a substantial fall in serum HDL-C level was found in consuming high-fat diet $(9.10 \pm 0.42 \mathrm{mg} /$ dL). Administration of $400 \mathrm{mg} / \mathrm{kg}$ b.w./day (p.o.) of AISE 


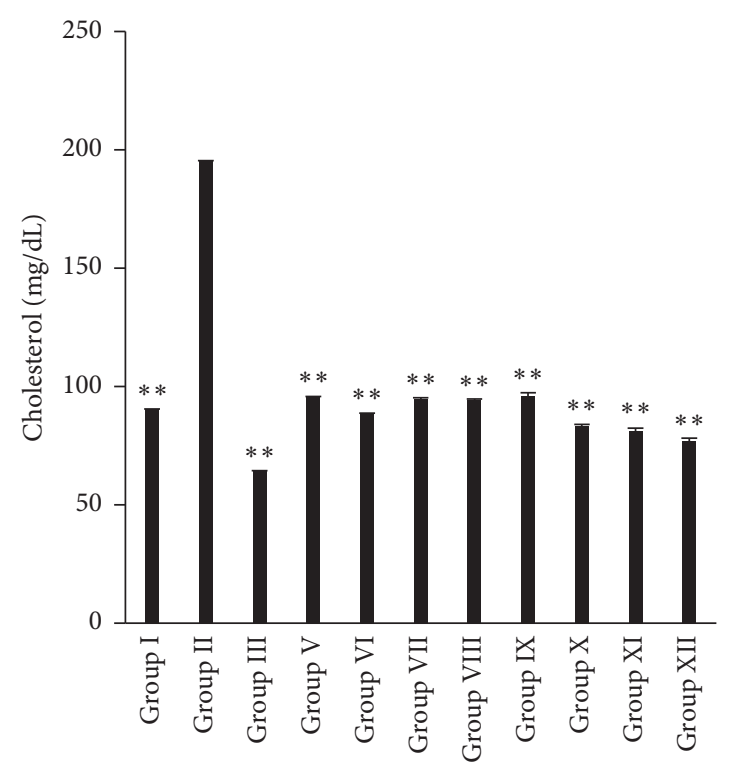

Groups

(a)

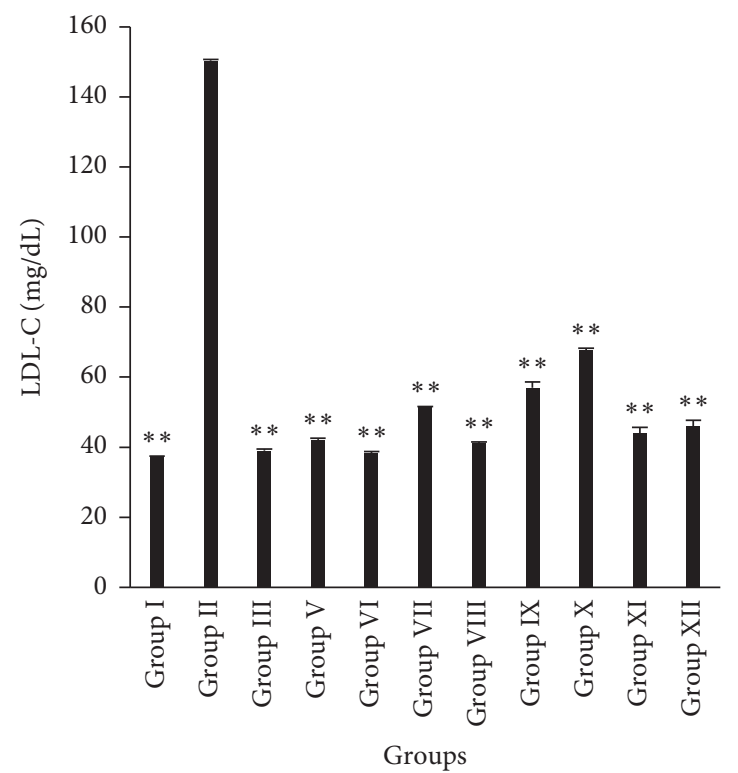

(c)

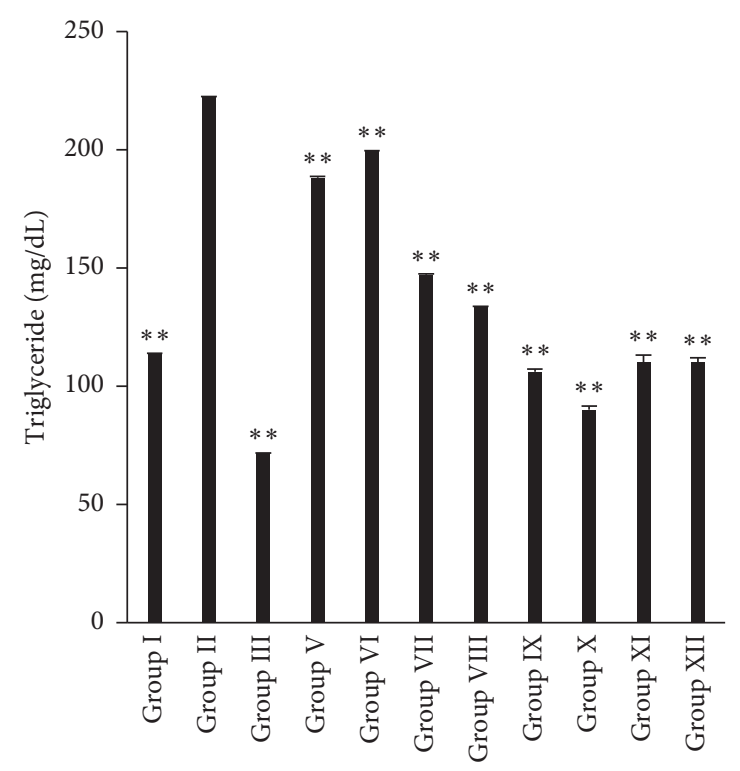

Groups

(b)

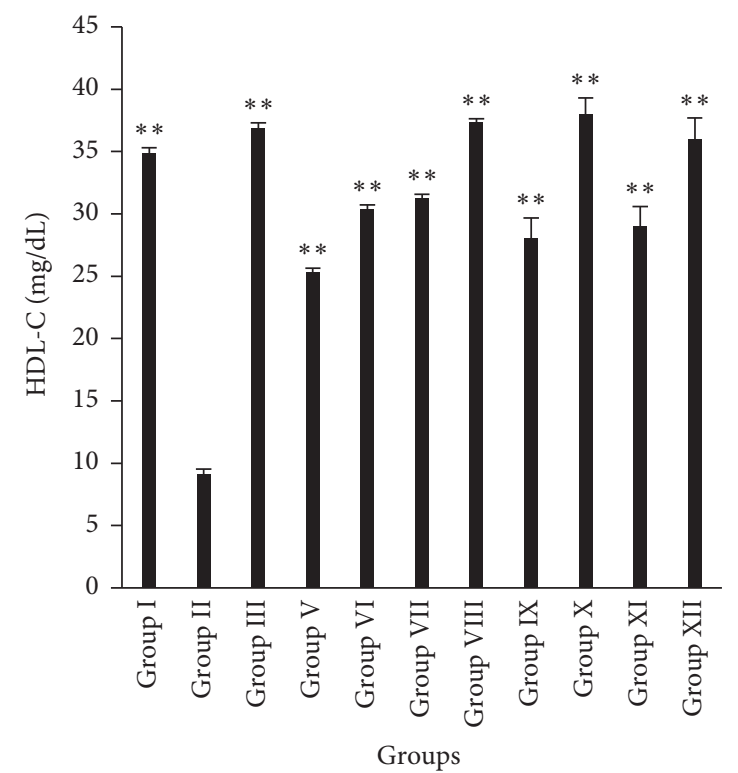

(d)

Figure 2: Estimation of cholesterol (a), triglyceride (b), LDL-C (c), HDL-C (d) in rats at the end of the treatment. Results are expressed in mean \pm SEM $(n=6) .\left(^{*}\right)$ indicates statistically significant difference from HFD group using ANOVA, followed by Dunnett's multiple comparison test $\left({ }^{*} p<0.05,{ }^{* *} p<0.01\right)$ where treatment groups were compared with Group II (atherogenic control). Group I= normal control, Group II = atherogenic control (HFD), Group III = atherogenic control $+3 \mathrm{mg} / \mathrm{kg}$ of Simvastatin, Group V=atherogenic control $+250 \mathrm{mg} / \mathrm{kg}$ ethanolic extract of A. ilicifolius (leaf), Group VI = atherogenic control $+500 \mathrm{mg} / \mathrm{kg}$ ethanolic extract of A. ilicifolius (leaf), Group VII = atherogenic control $+250 \mathrm{mg} / \mathrm{kg}$ methanolic extract of A. ilicifolius (leaf), Group VIII $=$ atherogenic control $+500 \mathrm{mg} / \mathrm{kg}$ methanolic extract of A. ilicifolius (leaf), Group IX = atherogenic control $+200 \mathrm{mg} / \mathrm{kg}$ methanolic extract of A. ilicifolius (stem), Group $\mathrm{X}=$ atherogenic control $+400 \mathrm{mg} / \mathrm{kg}$ methanolic extract of A. ilicifolius (stem), Group XI = atherogenic control $+200 \mathrm{mg} / \mathrm{kg}$ ethanolic extract of A. ilicifolius (stem), Group XII = atherogenic control $+400 \mathrm{mg} / \mathrm{kg}$ ethanolic extract of $A$. ilicifolius (stem). LDL-C = low-density lipoprotein cholesterol; HDL-C = high-density lipoprotein cholesterol.

and AISM extensively lowered serum cholesterol and triglyceride respectively $(77.00 \pm 1.08 \mathrm{mg} / \mathrm{dL}$ and $90.00 \pm 1.47 \mathrm{mg} / \mathrm{dL}$ ). Conversely, treatment with $400 \mathrm{mg} / \mathrm{kg}$ b.w./day (p.o.) of AISM exhibited maximum upraise in serum HDL-C level $(38.00 \pm 1.29 \mathrm{mg} / \mathrm{dL})$.
Estimation of the atherogenic index and serum ratios of TC/HDL-C and LDL-C/HDL-C of different groups of rats are summarized in Table 7 . A significant difference $(p<0.05$ and $p<0.01)$ in the atherogenic index of different treatment groups was compared with the atherogenic animals. 
TABLE 7: Estimation of atherogenic index and ratios of serum TC/HDL-C and LDL-C/HDL-C.

\begin{tabular}{lcccc}
\hline Group & Treatment & Atherogenic index & TC/HDL-C & LDL-C/HDL-C \\
\hline Group I & Normal diet & $0.53 \pm 0.20^{*}$ & $2.55 \pm 0.03^{* *}$ & $1.04 \pm 0.03^{* *}$ \\
Group II & High-fat diet (HFD) & $1.40 \pm 0.26$ & $21.49 \pm 0.36$ & $16.42 \pm 0.36$ \\
Group III & Simvastatin $3 \mathrm{mg} / \mathrm{kg} \mathrm{bw} / \mathrm{p} .0$. & $0.28 \pm 0.10^{* *}$ & $1.7 \pm 0.23^{* *}$ & $1.05 \pm 0.03^{* *}$ \\
Group V & HFD + AILE 250 mg/kg bw/p.o. & $0.88 \pm 0.09^{\eta}$ & $3.83 \pm 0.27^{* *}$ & $1.8 \pm 0.23^{* *}$ \\
Group VI & HFD + AILE $500 \mathrm{mg} / \mathrm{kg} \mathrm{bw/p.o.}$ & $0.68 \pm 0.17^{\eta}$ & $2.86 \pm 0.17^{* *}$ & $1.34 \pm 0.23^{* *}$ \\
Group VII & HFD + AILM 250 mg/kg bw/p.o. & $0.64 \pm 0.19^{*}$ & $3.04 \pm 0.04^{* *}$ & $1.57 \pm 0.38^{* *}$ \\
Group VIII & HFD + AILM 500 mg/kg bw/p.o. & $0.59 \pm 0.19^{*}$ & $2.59 \pm 0.26^{* *}$ & $1.14 \pm 0.16^{* *}$ \\
Group IX & HFD + AISE 200 mg/kg bw/p.o. & $0.56 \pm 0.20^{*}$ & $3.36 \pm 0.24^{* *}$ & $2.03 \pm 0.02^{* *}$ \\
Group X & HFD + AISE 400 mg/kg bw/p.o. & $0.36 \pm 0.12^{* *}$ & $2.25 \pm 0.19^{* *}$ & $1.88 \pm 0.24^{* *}$ \\
Group XI & HFD + AISM 200 mg/kg bw/p.o. & $0.57 \pm 0.19^{*}$ & $2.71 \pm 0.35^{* *}$ & $1.55 \pm 0.22^{* *}$ \\
Group XII & HFD + AISM 400 mg/kg bw/p.o. & $0.49 \pm 0.20^{* *}$ & $2.18 \pm 0.18^{* *}$ & $1.27 \pm 0.30^{* *}$ \\
\hline
\end{tabular}

Values are expressed as mean \pm SEM of 6 rats; ANOVA was used for multiple comparison where the treatment groups are compared with Group II. Here, ${ }^{*} p<$ $0.05,{ }^{* *} p<0.01$ and $\eta=$ non-significant $(p>0.05)$. TC $=$ total cholesterol; LDL-C $=$ low-density lipoprotein cholesterol; HDL-C = high-density lipoprotein cholesterol; AILE = ethanolic extract of A. ilicifolius (leaf), AILM = methanolic extract of A. ilicifolius (leaf), AISE = ethanolic extract of A. ilicifolius (stem), AISM = methanolic extract of $A$. ilicifolius (stem).

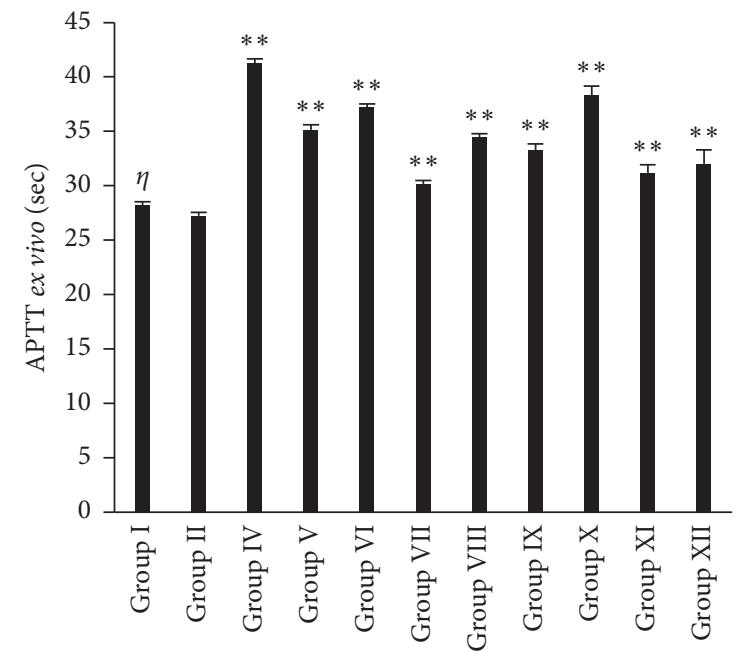

Groups

(a)

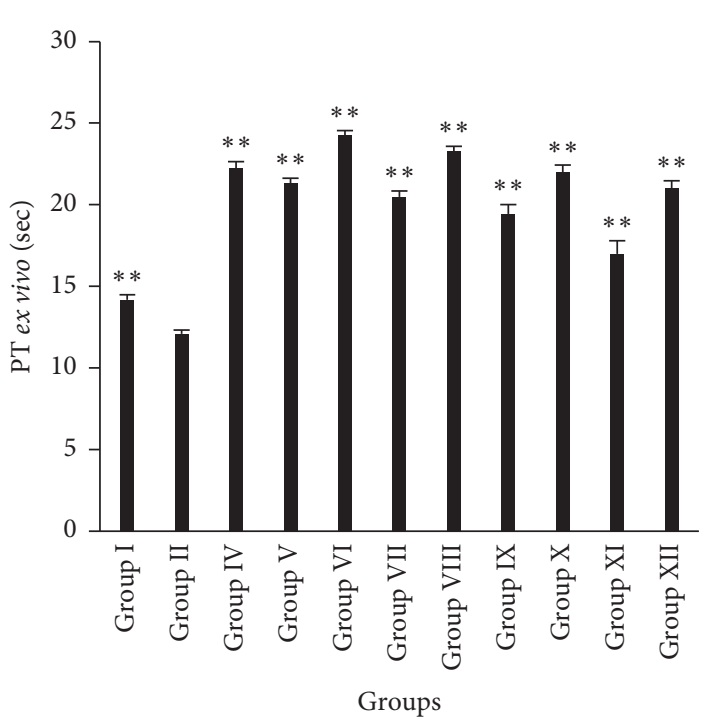

(b)

Figure 3: Anticoagulant effect of A. ilicifolius in rats; activated partial thromboplastin time assay (a) and prothrombin time assay (b). Results are expressed in mean $\pm \operatorname{SEM}(n=6)$. $\left(^{*}\right)$ indicates statistically significant and $(\eta)$ indicates non-significant difference from HFD group using ANOVA, followed by Dunnett's multiple comparison test $\left({ }^{*} p<0.05,{ }^{* *} p<0.01\right)$ where treatment groups were compared with Group II (atherogenic control). Group I = normal control, Group II = atherogenic control (HFD), Group IV = atherogenic control + Warfarin $2 \mathrm{mg} /$ $\mathrm{kg}$, Group $\mathrm{V}=$ atherogenic control $+250 \mathrm{mg} / \mathrm{kg}$ ethanolic extract of A. ilicifolius (leaf), Group VI=atherogenic control $+500 \mathrm{mg} / \mathrm{kg}$ ethanolic extract of A. ilicifolius (leaf), Group VII = atherogenic control $+250 \mathrm{mg} / \mathrm{kg}$ methanolic extract of A. ilicifolius (leaf), Group $\mathrm{VIII}=$ atherogenic control $+500 \mathrm{mg} / \mathrm{kg}$ methanolic extract of A. ilicifolius (leaf), Group IX = atherogenic control $+200 \mathrm{mg} / \mathrm{kg} \mathrm{methanolic}$ extract of $A$. ilicifolius (stem), Group X = atherogenic control $+400 \mathrm{mg} / \mathrm{kg}$ methanolic extract of $A$. ilicifolius (stem), Group XI = atherogenic control $+200 \mathrm{mg} / \mathrm{kg}$ ethanolic extract of A. ilicifolius (stem), Group XII = atherogenic control $+400 \mathrm{mg} / \mathrm{kg}$ ethanolic extract of $A$. ilicifolius (stem).

However, oral administration of $400 \mathrm{mg} / \mathrm{kg}$ b.w./day of AISM for 15 days strikingly reduced atherogenic index $(0.36 \pm 0.12)$ that is relevant to the data of standard drug $(3 \mathrm{mg} / \mathrm{kg}$ b.w./day, p.o. of Simvastatin) $(0.28 \pm 0.10)$. In comparison to the atherogenic model, the ratios of $\mathrm{TC} /$ HDL-C and LDL-C/HDL-C were significantly lower $(p<0.01)$ in normal control and treatment groups. Among the treatment groups, Group XII and Group VIII demonstrated the highest depletion of serum ratio of TC/HDL-C and LDL-C/HDL-C, respectively.
3.7. The Anticoagulant Effect of A. ilicifolius. The results of $e x$ vivo coagulation assays for APTT and PT are demonstrated in Figure 3. The clotting time of APTT and PT was observed to be significantly high $(p<0.01)$ in rats treated with various plant extracts compared with atherogenic control after completion of dosing. Group X showed a maximum increase in APTT clotting time $(38.35 \pm 0.83 \mathrm{sec})$, which was similar to the standard drug $(2 \mathrm{mg} / \mathrm{kg}$ b.w./day, p.o. of Warfarin) $(41.23 \pm 0.44 \mathrm{sec})$. Animals of Group VI showed a larger clotting time of PT $(24.23 \pm 0.32 \mathrm{sec})$ than the group that 


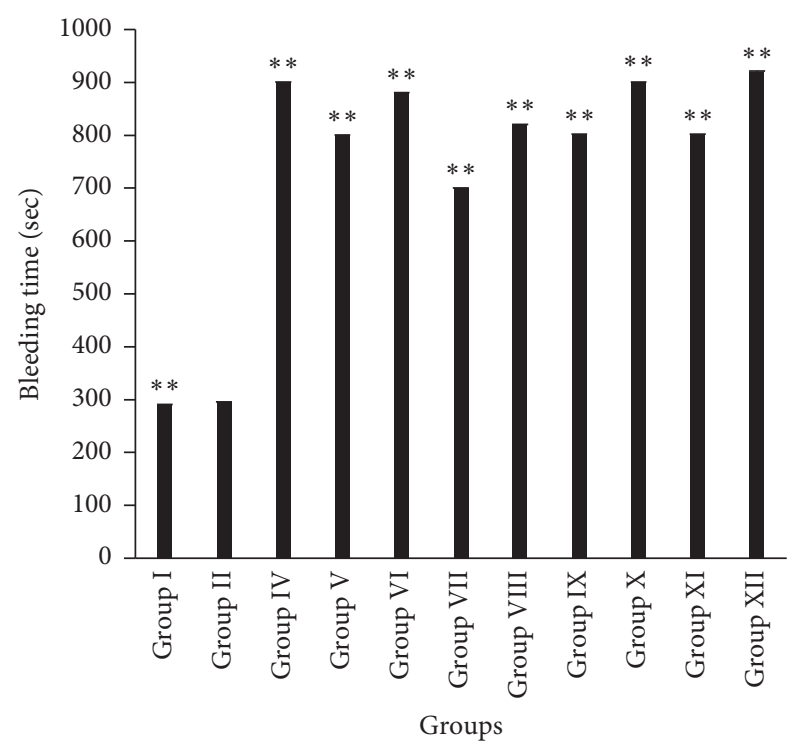

(a)

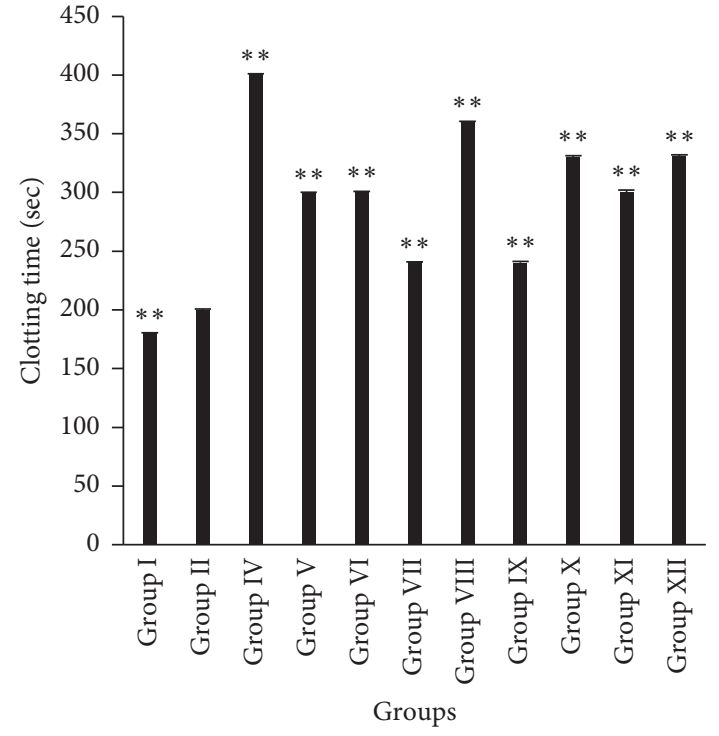

(b)

FIGURE 4: Determination of bleeding (a) and clotting (b) time in rats. Results are expressed in mean \pm SEM $(n=6)$. $\left({ }^{*}\right)$ indicates statistically significant difference from HFD group using ANOVA, followed by Dunnett's multiple comparison test $\left({ }^{*} p<0.05\right.$, $\left.{ }^{* *} p<0.01\right)$ where treatment groups were compared with Group II (atherogenic control). Group I = normal control, Group II = atherogenic control (HFD), Group IV = atherogenic control + Warfarin $2 \mathrm{mg} / \mathrm{kg}$, Group V = atherogenic control $+250 \mathrm{mg} / \mathrm{kg}$ ethanolic extract of A. ilicifolius (leaf), Group VI =atherogenic control $+500 \mathrm{mg} / \mathrm{kg}$ ethanolic extract of A. ilicifolius (leaf), Group VII $=$ atherogenic control $+250 \mathrm{mg} / \mathrm{kg}$ methanolic extract of A. ilicifolius (leaf), Group VIII = atherogenic control $+500 \mathrm{mg} / \mathrm{kg}$ methanolic extract of A. ilicifolius (leaf), Group $\mathrm{IX}=$ atherogenic control $+200 \mathrm{mg} / \mathrm{kg}$ methanolic extract of A. ilicifolius (stem), Group X=atherogenic control $+400 \mathrm{mg} / \mathrm{kg} \mathrm{methanolic}$ extract of A. ilicifolius (stem), Group XI = atherogenic control $+200 \mathrm{mg} / \mathrm{kg}$ ethanolic extract of $A$. ilicifolius (stem), Group XII = atherogenic control $+400 \mathrm{mg} / \mathrm{kg}$ ethanolic extract of A. ilicifolius (stem).

received treatment with a standard drug $(22.23 \pm 0.41 \mathrm{sec})$. However, there were no significant changes in APTT clotting time found in rats of the normal control group $(28.23 \pm 0.30 \mathrm{sec})$ as compared to the atherogenic control group $(27.23 \pm 0.34 \mathrm{sec})$.

Furthermore, the results of in vivo bleeding time assay revealed that high doses of plant extracts (Group VI, Group $\mathrm{X}$, and Group XII) showed data $(880.20 \pm 0.33 ; 900.00 \pm 0.82$, and $920 \pm 1.6 \mathrm{sec}$, respectively) similar to Warfarin $(900.00 \pm 0.44 \mathrm{sec})$ as demonstrated in Figure 4. Nevertheless, clotting time was markedly prolonged in rats of Group VIII $(359.98 \pm 0.43 \mathrm{sec})$.

\section{Effect of the Alcoholic Extracts of A. ilicifolius on Histopathology of Aorta, Liver, and Kidney}

4.1. Aorta. Histopathological changes of the cross section of rat aorta after treatment with different doses of plant extracts are demonstrated in Figure 5. Under the microscopic examination, a normal cardiac aorta architecture was observed in rats of a normal control group where the endothelial cells and smooth muscle cells are underlying much prominently (Figure 5(a)). Conversely, atherogenic rat aorta showed excessive accumulation of lipid droplets had been found causing the development of innumerable macrophage-derived foam cells (MFC) under the thin endothelium lining, which resulted in the migration of smooth muscle cell (SMC) within the area of lipid droplets resulting formation of atherosclerotic lesions with substantial destruction of smooth muscle cells, endothelial cells, and lymphocytes cells (Figure 5(b)). Administered high doses (500 and $400 \mathrm{mg} / \mathrm{kg}$ b.w./day, p.o., respectively) of AILM, AILE, and AISE exhibited aorta with fewer macrophage-derived foam cells and lesser destruction of endothelial cells when compared to the atherogenic control group (Figures 5(g), 5(i), and 5(k)). A similar observation was made in rats treated with standard drugs showing much conserved cellular architecture (Figure 5(c)).

4.2. Liver. The liver histology of rats varied among different groups, as represented in Figure 6. Normal histology of liver tissue was observed in Group I (Figure 6(a)). However, extensive fat deposition around the central vein area was seen in the microscopic image of liver tissue of rats that consumed high-fat diet resulting in an enlarged central vein, infiltration of inflammatory cells with cellular necrosis, and development of fibrosis (Figure 6(b)). This confirmed the evolution of microvesicular steatosis in the liver. The oral medication of $500 \mathrm{mg} / \mathrm{kg}$ b.w./day of AILM and $400 \mathrm{mg} / \mathrm{kg} \mathrm{b.w./day} \mathrm{of}$ AISM and AISE showed much-improved liver tissues with the presence of compact and healthy hepatocytes (Figures 6(g), $6(\mathrm{i})$, and $6(\mathrm{k}))$. This was the case found in rats medicated with $3 \mathrm{mg} / \mathrm{kg}$ b.w./day, p.o. of Simvastatin (Figure 6(c)).

4.3. Kidney. The morphology of normal rat kidneys showed a regular arrangement of cells in the outer portion of the 


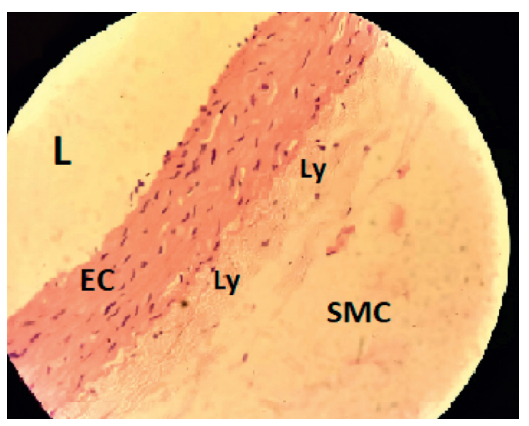

(a)

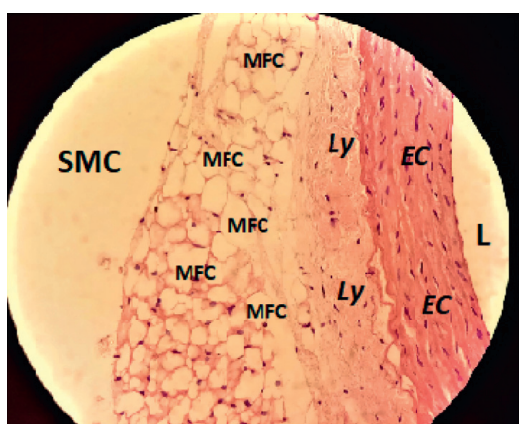

(d)

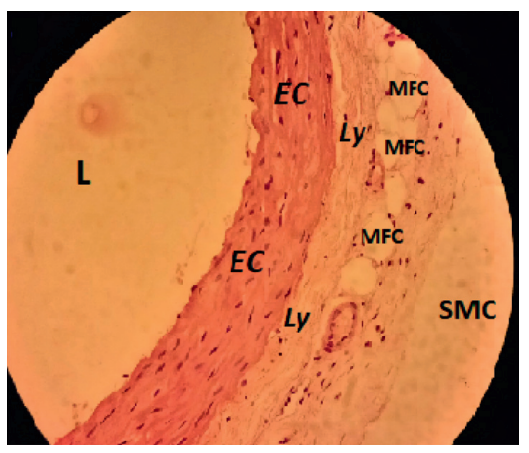

(g)

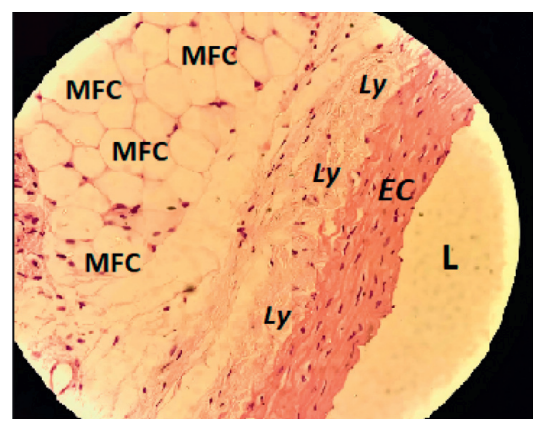

(b)

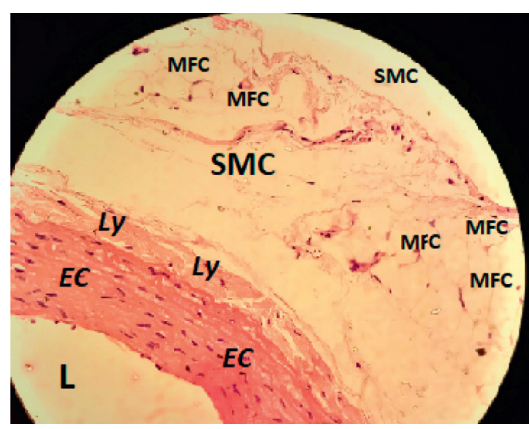

(e)

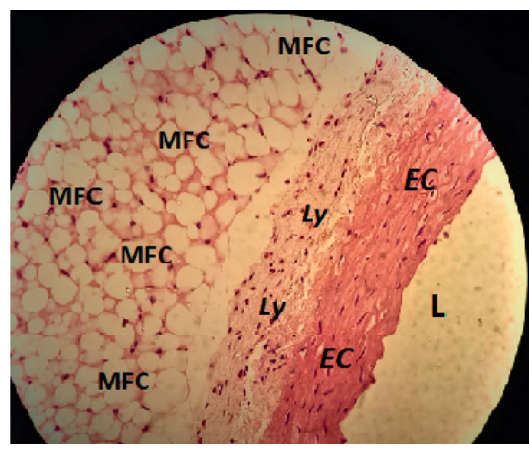

(h)

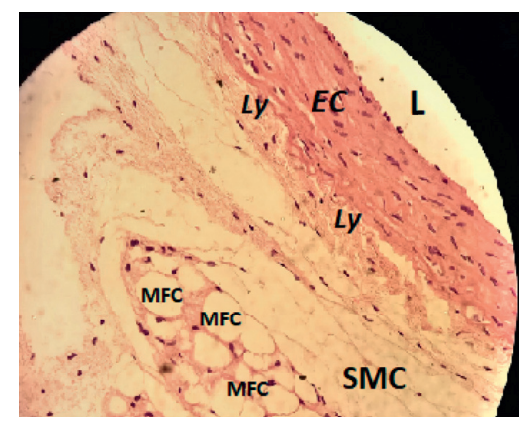

(c)

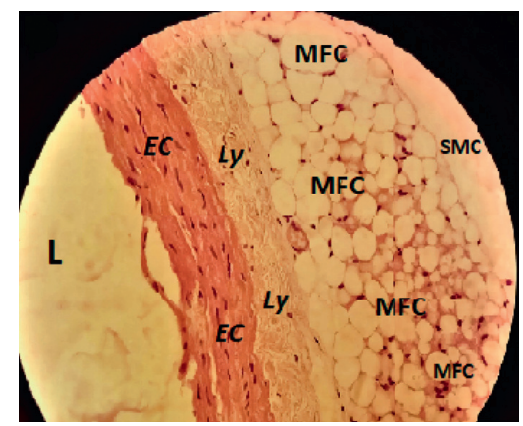

(f)

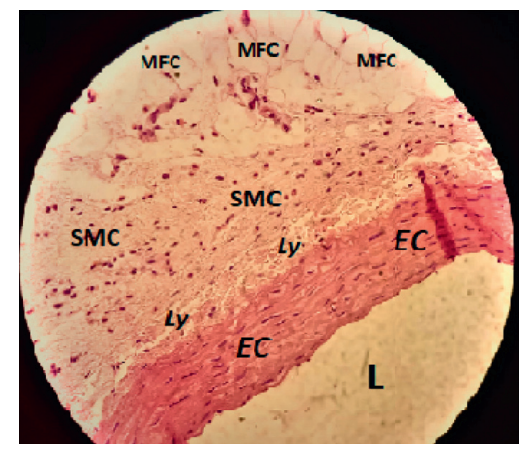

(i)

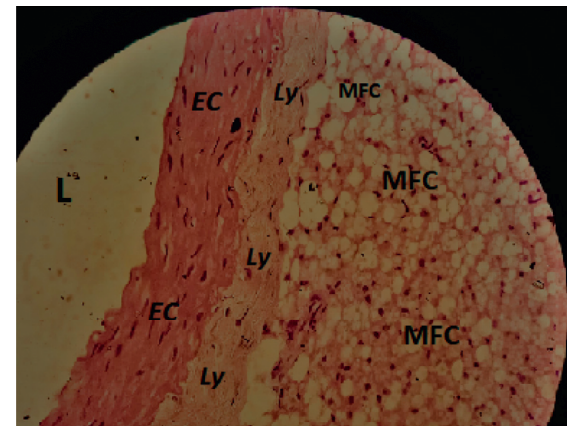

(j)

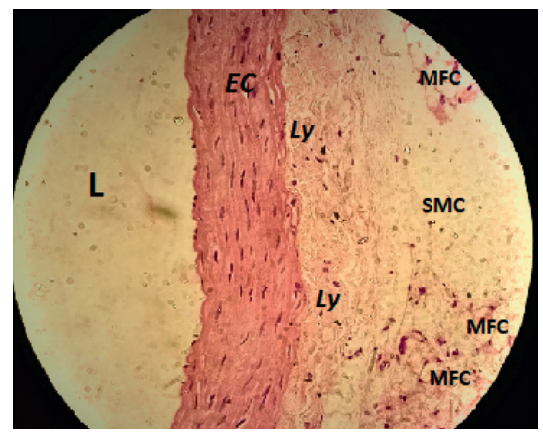

$(\mathrm{k})$

FigURE 5: Histopathology of rat aorta showing vascular lumen (L), endothelial cells (EC), group of lymphocytes (Ly), smooth muscle cells (SMC), and macrophage-derived foam cells (MFC). (a): Group I = normal control, (b): Group II = atherogenic control (HFD), (c): Group $\mathrm{III}=$ atherogenic control $+3 \mathrm{mg} / \mathrm{kg}$ of Simvastatin, (d): Group V = atherogenic control $+250 \mathrm{mg} / \mathrm{kg}$ ethanolic extract of A. ilicifolius (leaf), (e): Group VI = atherogenic control $+500 \mathrm{mg} / \mathrm{kg}$ ethanolic extract of A. ilicifolius (leaf), (f): Group VII = atherogenic control $+250 \mathrm{mg} / \mathrm{kg}$ methanolic extract of A. ilicifolius (leaf), (g): Group VIII = atherogenic control $+500 \mathrm{mg} / \mathrm{kg}$ methanolic extract of A. ilicifolius (leaf), (h): Group IX = atherogenic control $+200 \mathrm{mg} / \mathrm{kg}$ methanolic extract of A. ilicifolius (stem), (i): Group X=atherogenic control $+400 \mathrm{mg} / \mathrm{kg}$ methanolic extract of $A$. ilicifolius (stem), (j): Group XI = atherogenic control $+200 \mathrm{mg} / \mathrm{kg}$ ethanolic extract of $A$. ilicifolius (stem), (k): Group XII = atherogenic control $+400 \mathrm{mg} / \mathrm{kg}$ ethanolic extract of A. ilicifolius (stem). Microscopic examination of each group was performed at 400X magnification, scale bar: $40 \mu \mathrm{m}$. 


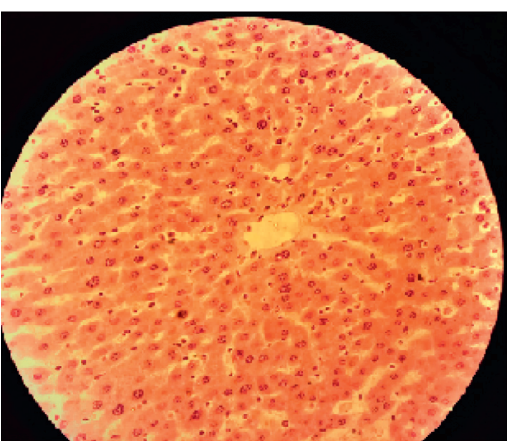

(a)

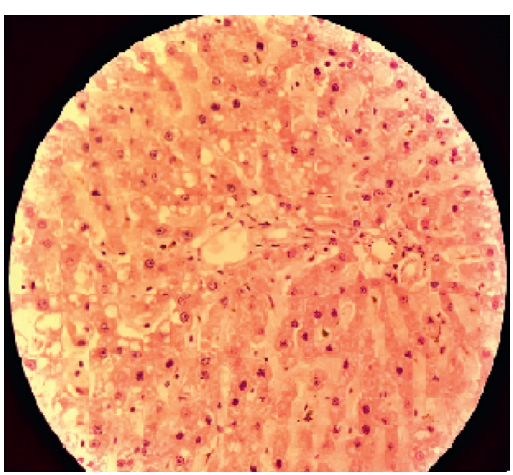

(d)

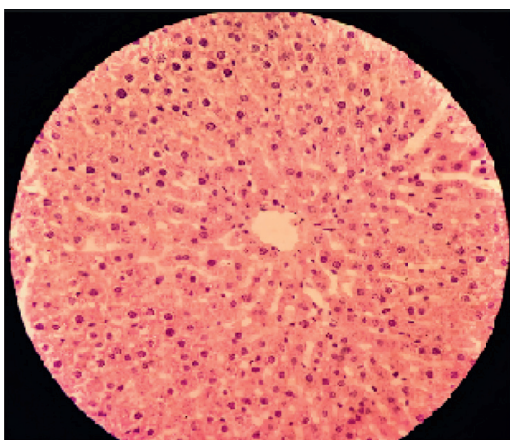

(g)

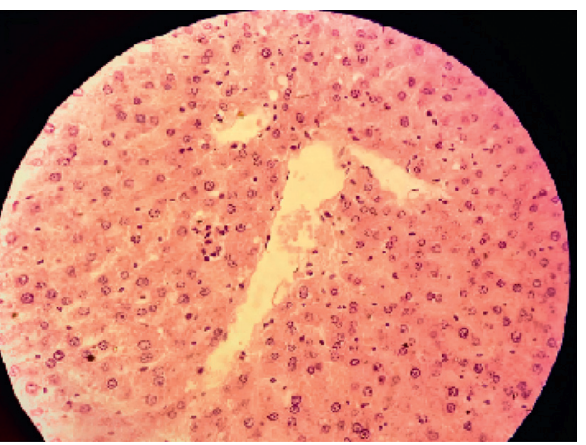

(j)

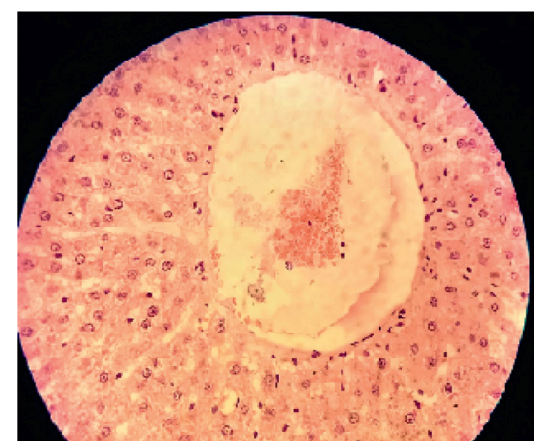

(b)

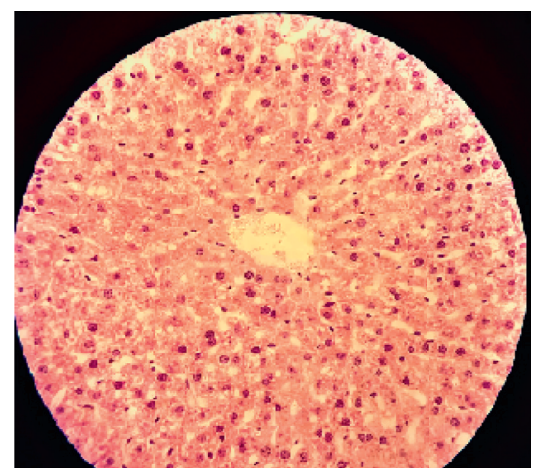

(e)

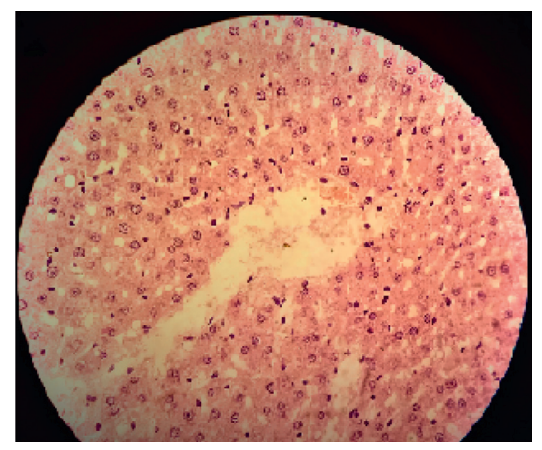

(h)

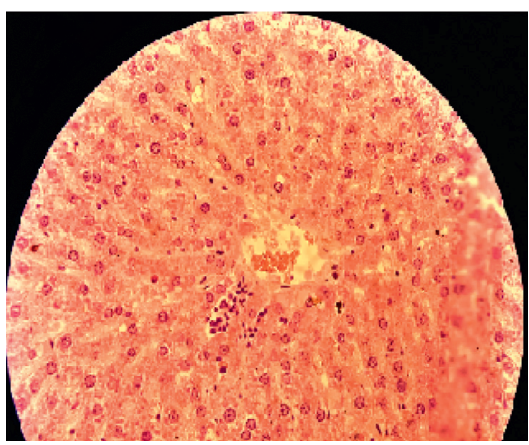

(c)

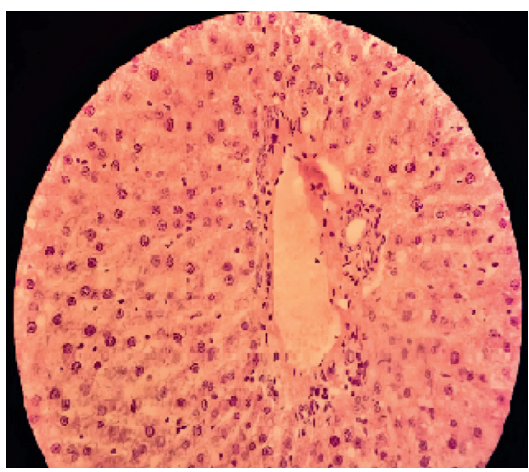

(f)

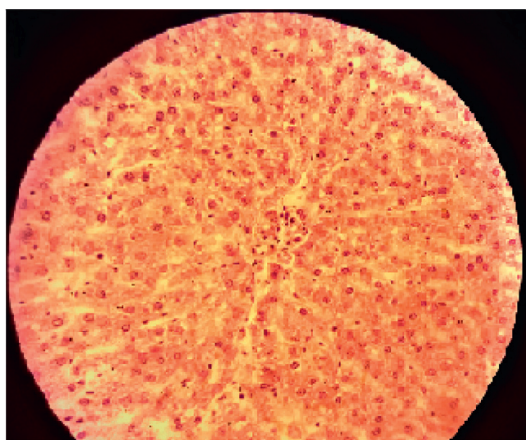

(i)

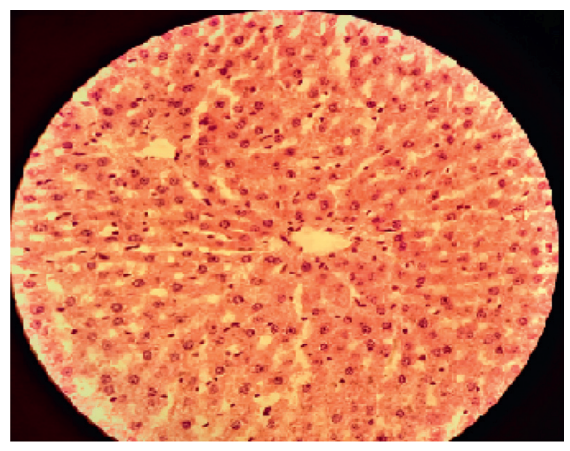

(k)

FIGURE 6: Histopathology of rat liver; (a): Group I = normal control, (b): Group II = atherogenic control (HFD), (c): Group III = atherogenic control $+3 \mathrm{mg} / \mathrm{kg}$ of Simvastatin, (d): Group V=atherogenic control $+250 \mathrm{mg} / \mathrm{kg}$ ethanolic extract of A. ilicifolius (leaf), (e): Group $\mathrm{VI}=$ atherogenic control $+500 \mathrm{mg} / \mathrm{kg}$ ethanolic extract of $A$. ilicifolius (leaf), (f): Group VII = atherogenic control $+250 \mathrm{mg} / \mathrm{kg} \mathrm{methanolic}$ extract of A. ilicifolius (leaf), (g): Group VIII = atherogenic control $+500 \mathrm{mg} / \mathrm{kg}$ methanolic extract of A. ilicifolius (leaf), (h): Group IX = atherogenic control $+200 \mathrm{mg} / \mathrm{kg}$ methanolic extract of A. ilicifolius (stem), (i): Group X = atherogenic control $+400 \mathrm{mg} / \mathrm{kg} \mathrm{methanolic}$ extract of A. ilicifolius (stem), (j): Group XI = atherogenic control $+200 \mathrm{mg} / \mathrm{kg}$ ethanolic extract of A. ilicifolius (stem), (k): Group $\mathrm{XII}=$ atherogenic control $+400 \mathrm{mg} / \mathrm{kg}$ ethanolic extract of $A$. ilicifolius (stem). Microscopic examination of each group was performed at 400X magnification, scale bar: $40 \mu \mathrm{m}$. 


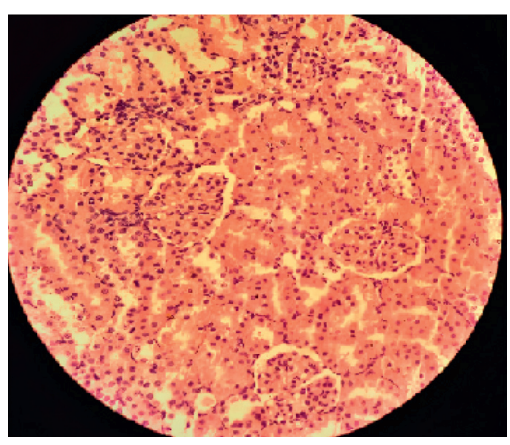

(a)

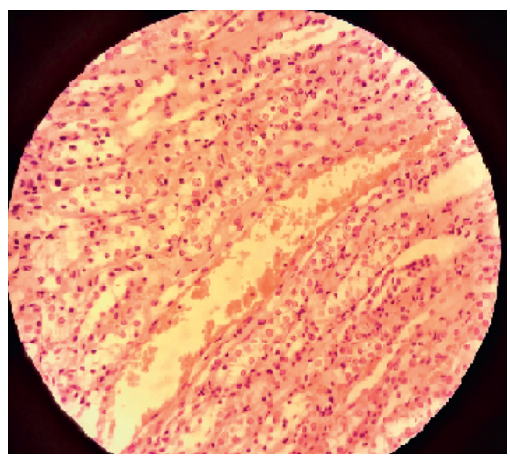

(d)

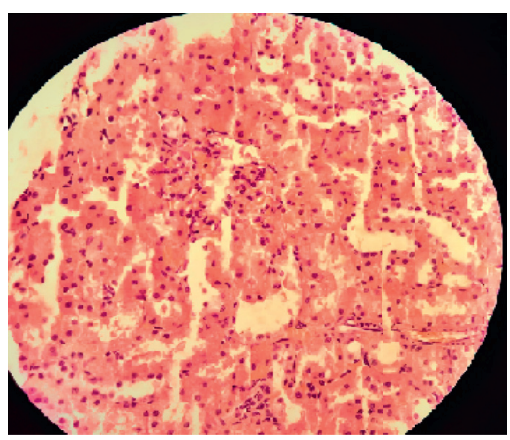

(g)

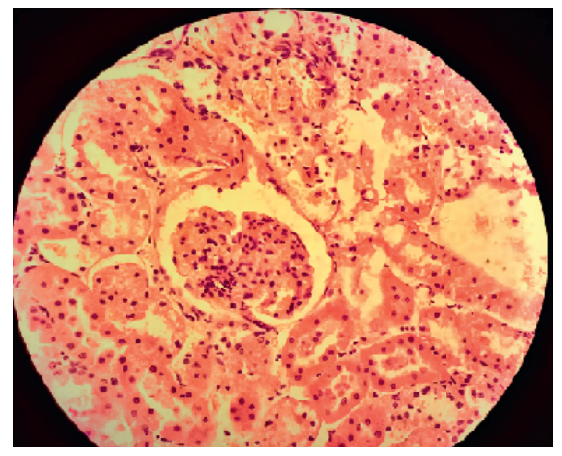

(j)

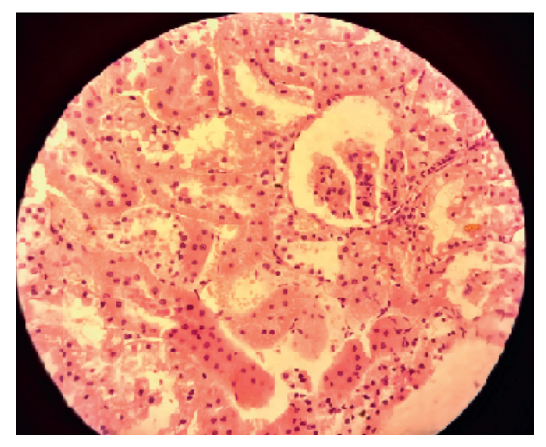

(b)

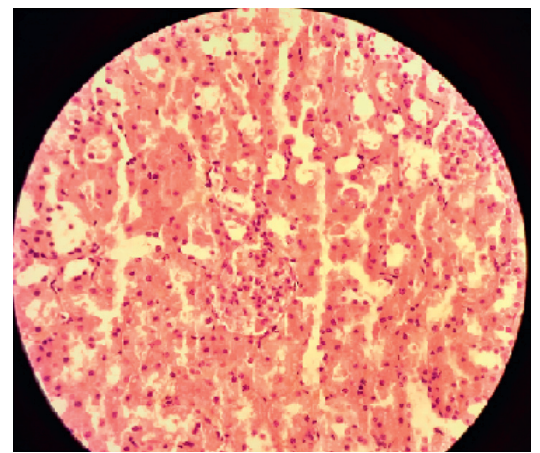

(e)

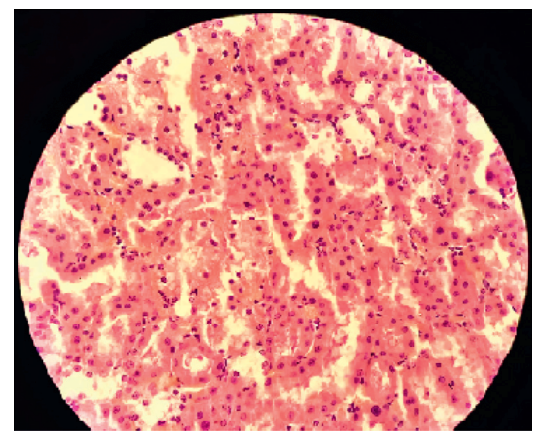

(h)

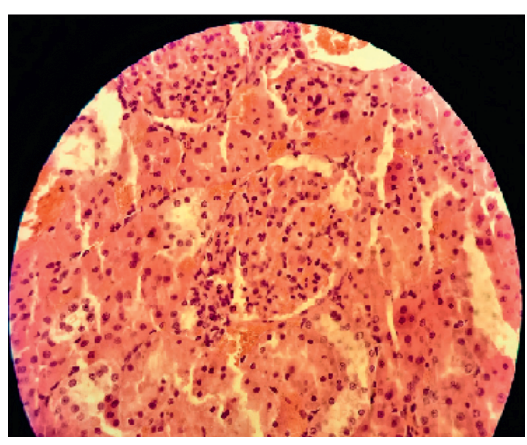

(c)

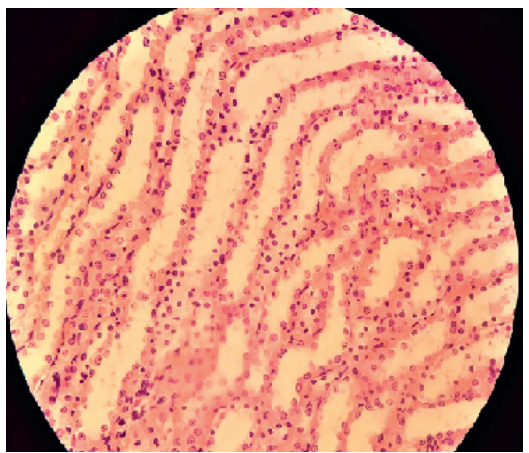

(f)

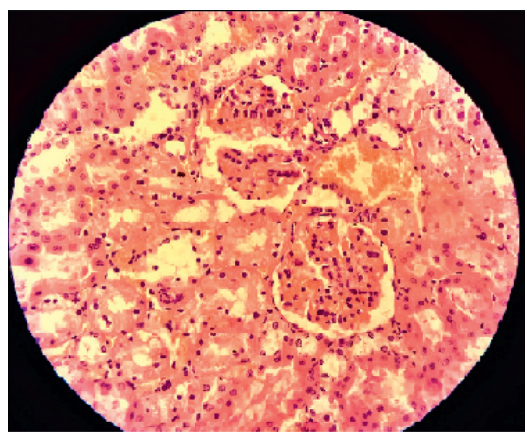

(i)

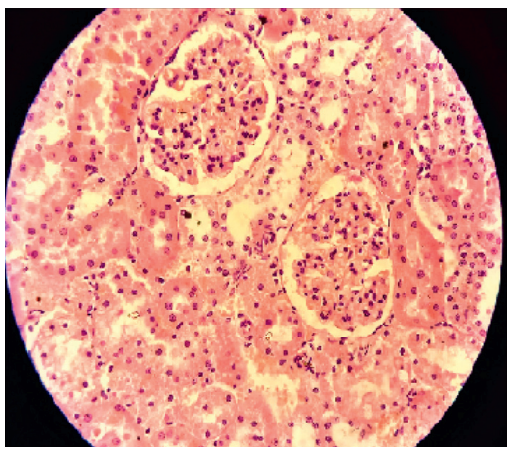

$(\mathrm{k})$

Figure 7: Histology of rat kidney; (a): Group I = normal control, (b): Group II = atherogenic control (HFD), (c): Group III = atherogenic control $+3 \mathrm{mg} / \mathrm{kg}$ of Simvastatin, (d): Group V = atherogenic control $+250 \mathrm{mg} / \mathrm{kg}$ ethanolic extract of A. ilicifolius (leaf), (e): Group $\mathrm{VI}=$ atherogenic control $+500 \mathrm{mg} / \mathrm{kg}$ ethanolic extract of $A$. ilicifolius (leaf), (f): Group VII = atherogenic control $+250 \mathrm{mg} / \mathrm{kg} \mathrm{methanolic}$ extract of A. ilicifolius (leaf), (g): Group VIII = atherogenic control $+500 \mathrm{mg} / \mathrm{kg}$ methanolic extract of A. ilicifolius (leaf), (h): Group IX = atherogenic control $+200 \mathrm{mg} / \mathrm{kg}$ methanolic extract of $A$. ilicifolius (stem), (i): Group X=atherogenic control $+400 \mathrm{mg} / \mathrm{kg} \mathrm{methanolic}$ extract of A. ilicifolius (stem), (j): Group XI = atherogenic control $+200 \mathrm{mg} / \mathrm{kg}$ ethanolic extract of A. ilicifolius (stem), (k): Group $\mathrm{XII}=$ atherogenic control $+400 \mathrm{mg} / \mathrm{kg}$ ethanolic extract of $A$. ilicifolius (stem). Microscopic examination of each group was performed at 400X magnification, scale bar: $40 \mu \mathrm{m}$. 
medulla of the kidney with minimum lipid deposition and many prominent glomeruli (Figure 7(a)). However, abnormal histology of rat kidneys was seen in groups that consumed lipid-rich diet and exhibited the presence of considerable fat accumulation around glomeruli and infiltration of inflammatory cells (Figure 7(b)). Pathological destruction of the kidney tissues was substantially reduced and normal architecture of glomeruli, collecting ducts, tubules, ascending, and descending loops of the kidney were observed in animals treated with the standard drug (Figure $7(\mathrm{c})$ ) as well as those that received $400 \mathrm{mg} / \mathrm{kg}$ b.w./ day, p.o. of AISE and AISM (Figures 7(i) and 7(k)).

\section{Discussion}

A. ilicifolius is acknowledged for its rich sources of several phytochemical constituents like steroids, triterpenoids, saponins, flavonoids, alkaloids, and tannins [3]. The whole and distinct plant parts have been employed for the purpose of therapeutic aid $[60,61]$. In our present study, alcoholic extracts of $A$. ilicifolius leaf and stem have been recruited to investigate its potentiality against atherosclerosis in the high-fat diet-fed rat model. We found several classes of bioactive compounds in both stem and leaf extracts of the plant (Table 3 ) that possess many health benefits due to their effectiveness in the process of drug discovery in traditional and pharmaceutical industries [62]. Literature data revealed that phenolic compounds are abundantly present in the alcoholic extracts of different parts of A. ilicifolius, particularly root and leaf [63-66]. These data support that the plant extract are directly associated with antioxidant activities since their hydroxyl group potentially absorbs and detoxifies the free radicals [67-72]. Free radicals are known to produce oxidative stress, for which several conditions like diabetes, atherosclerosis, arthritis, and seizure may arise [73]. This can be avoided by the consumption of antioxidants from natural sources that create a balance between the availability of free radicals and endogenous antioxidants in blood $[74,75]$. The current study displayed the antioxidant power of the plant extracts even at the lowest concentration $(1.25 \mu \mathrm{g} / \mathrm{mL})$, indicating a considerable amount of phenolic compounds within the extract. The study further revealed that the leaf extracts of A. ilicifolius (AILM and AILE) possess better antioxidant properties with the lowest $\mathrm{IC}_{50}$ values $(5.89 \mu \mathrm{g} / \mathrm{mL}$ and $6.59 \mu \mathrm{g} / \mathrm{mL})$ as compared to the root extracts of the plant. Besides, the leaves of $A$. ilicifolius were found as a potential source of natural antioxidants in a study of the recent year [72]. Nevertheless, the antioxidant capacity of plant extracts was found less than that of ascorbic acid, which reflects the results from previous studies on this mangrove plant material $[19,76]$.

Regular consumption of high-fat diet (HFD) leads to obesity, which encourages the body to store more fat within the tissues and organs and gain weight [40]. The presence of a prominent amount of fat in diet also gives rise to aortic atherosclerosis by elevating serum TC, TG, and LDL-C [76]. Our study demonstrated that the administration of plant extracts potentially reduced body weight. Obesity associated with dyslipidemia is considered one of the prominent causes of the evolution of cardiovascular diseases [77]. A high concentration of cholesterol in the blood leads to oxidized LDL-C, which is engulfed by existing macrophages within endocardial endothelium as lipid-rich foam cells, and eventually develops lesions of atherosclerotic plaque inside the arterial wall [77]. Hence, minimization of serum cholesterol, triglyceride, and LDL-C levels plays a prominent role in the deterrence of cardiovascular disorders, which could be achieved by administering antioxidants from natural sources $[77,78]$.

According to the present experiment, analysis of total lipid concentrations manifested that $400 \mathrm{mg} / \mathrm{kg}$ b.w./day, p.o. of AISM extensively declined serum triglyceride and cholesterol levels in rats. In comparison, maximal depletion of total LDL-C level was found in rats receiving medication of $500 \mathrm{mg} / \mathrm{kg}$ b.w./day, p.o. of AILE. Nevertheless, the highest serum HDL-C level was observed in animals that received $400 \mathrm{mg} / \mathrm{kg}$ b.w./day, p.o. of AISM. A low HDL-C level and a high level of LDL-C level are directly linked to the likelihood of various cardiovascular diseases since HDL-C potentially transfers excess cholesterol from the arteries and tissues [79, 80].

An elevated atherogenic index is considered one of the significant markers of atherosclerosis [11]. In our study, the atherogenic condition promisingly improved in animals that encountered a dose of $400 \mathrm{mg} / \mathrm{kg}$ b.w./day, p.o. of AISE and AISM. Several past pieces of evidence underpin the fact that a lipid-rich diet is potentially accountable for vascular damage and oxidative stress due to the presence of excessive TC, TG, and LDL-C in the blood, which could lead to clinical consequences like heart attack, stroke, or other fatal condition [81, 82]. Furthermore, unconventional fat metabolism in the body helps expand the ratios of TC/HDL-C and LDL$\mathrm{C} / \mathrm{HDL}-\mathrm{C}$ in serum [83]. The present observation evidenced that high doses (400 and $500 \mathrm{mg} / \mathrm{kg}$ b.w./day, p.o.) of AILM and AISM strongly declined these ratios confirming significant lowering of fat content within the body. The presence of phenols and flavonoids can justify this statement and terpenoids in the plant extract. They strive for the antioxidant effect that controls lipid metabolism by minimizing inflammatory, fibro-proliferative, and vascular disorders [84-88].

The histopathology report proclaimed the atherosclerotic lesion incident within the arterial walls of high-fat dietfed rats improved by high doses (400 and $500 \mathrm{mg} / \mathrm{kg}$ b.w./ day, p.o.) of the plant extracts. Besides, a stockpile of fat within the tissues massively interrupted the regular morphology of liver and kidney tissues of atherogenic rats that were ameliorated to near normalcy by high doses of plant extracts.

The diuretic properties of $A$. ilicifolius were evidenced by a previous study where the presence of flavonoids and glycosides was believed to produce diuresis [89]. Regarding the fact that diuretics are used as therapy for hypertension, the present investigation was deliberated to assess the antihypertensive properties of $A$. ilicifolius. Current data showed treatment with $500 \mathrm{mg} / \mathrm{kg}$ b.w./day (p.o.) of AILM potentially lowered SBP to a normal level. Literature data support the certainty of the relationship between oxidative stress and 
hypertension progression by building up uncontrolled free radicals like ROS (reactive oxygen species) [90-92]. Moreover, mangrove species like A. ilicifolius consist of many antioxidant enzymes that exhibit defensive action against the detrimental consequences of ROS [93]. On that account, our work suggests that the antioxidant response by different extracts of $A$. ilicifolius could be the reason for their anti-hypertensive action. Besides, former research reported that a high HDL-C level contributes to the de-escalation of blood pressure [94], which corresponds to our present results.

Furthermore, the ethanolic leaf and aqueous root extracts of A. ilicifolius have been reported to possess anticoagulant potentiality at a higher dose in recent studies $[72,94]$. Our study manifested that high doses (400 and $500 \mathrm{mg} / \mathrm{kg}$ b.w./day, p.o.) of AILM and AISE predominantly decreased blood coagulation time. The accountability for the attainment of anticoagulant action of the plant extracts could be due to high level of flavonoids since compounds that exert antioxidant effect are responsible for anticoagulation [95].

Our work demonstrated that alcoholic extracts of both leaf and stem of A. ilicifolius could be a potential source of multiple phytoconstituents that play essential roles in forestalling oxidative stress, atherosclerosis, hypertension, and blood clotting within the body. In general, alcohols, explicitly methanol, are considered promising solvent systems for extraction technique since a number of active compounds, namely, flavonoids, phenols, tannins, and saponins, are found on phytochemical screening of plant extracts [96]. Methanol, however, turned up to be a better solvent system based on previous findings as the solvent is more effective in dissolving the active chemical moieties in the cells as it helps to perforate cellular membrane of the plant material to infiltrate the intracellular components [19].

\section{Conclusion}

To summarize, the present investigation documented both leaf and stem of A. ilicifolius as beneficiary herbs for the prevention of cardiac diseases by ameliorating various conditions like oxidative stress, obesity, hyperlipidemia, and high blood pressure. Based on biochemical tests and histopathology of distinguished tissues (aorta, liver, and kidney), our study manifested that alcoholic leaf and stem extracts were effective against atherosclerosis in a dosedependent approach. Also, the blood-thinning properties of the plant extract further support its usefulness as a medicinal plant for the management of cardiovascular diseases. The present data confirm that doses of 400 and $500 \mathrm{mg} / \mathrm{kg}$ b.w./ day (p.o.) of stem and leaf extracts were most effective against all parameters used for assessing the atherogenic condition. However, being a first-hand report, the current work suggests more investigations on quantifying and isolating the active constituents and their metabolites in leaves and stem of $A$. ilicifolius to justify the plant as a promising source of the secondary therapeutic scheme against atherosclerosis.

\section{Abbreviations}

A. ilicifolius: Acanthus ilicifolius

DPPH: 2,2-Diphenyl-1-picrylhydrazyl

SBP: $\quad$ Systolic blood pressure

HFD: $\quad$ High-fat diet

TC: $\quad$ Total cholesterol

TG $=$ : $\quad$ Triglyceride

HDL-C: High-density lipoprotein cholesterol

LDL-C: $\quad$ Low-density lipoprotein cholesterol

APTT: $\quad$ Activated partial thromboplastin time

PT: $\quad$ Prothrombin time

SEM: $\quad$ Standard error mean

AILE: $\quad$ Ethanolic extract of A. ilicifolius (leaf)

AILM: $\quad$ Methanolic extract of A. ilicifolius (leaf)

AISE: $\quad$ Ethanolic extract of A. ilicifolius (stem)

AISM: $\quad$ Methanolic extract of A. ilicifolius (stem).

\section{Data Availability}

All data contained within the paper.

\section{Disclosure}

RK and MMB are the co-first authors.

\section{Conflicts of Interest}

The authors declare that they have no conflicts of interest.

\section{Authors' Contributions}

RK and MSR made significant contributions to constructing and conducting the experiment. RK, TI, and SIK performed all experimental tasks in the laboratory. Data collection, statistical analysis, and interpretation were done by RK, AFK, and MMB. The article was written by RK and MSR. Critical revision of the article was done by RK, AFK, MSU, MTK, MAA, and MSR. RK and MMB contributed equally to the work and RK and MSR shared the correspondence equally. MSR revised critically and submitted the manuscript. All authors read and approved the final manuscript.

\section{Acknowledgments}

The authors acknowledge the Department of Pharmacy, Primeasia University, Dhaka, Bangladesh, and Phytochemical Laboratory of University of Dhaka, Dhaka, Bangladesh, for providing funding to accomplish the research. The authors also acknowledge Prof. Dr. Md. Shah Amran (Department of Pharmaceutical Chemistry, University of Dhaka) for his scientific assistance.

\section{References}

[1] M. Nebula, H. S. Harisankar, and N. Chandramohanakumar, "Metabolites and bioactivities of Rhizophoraceae mangroves," Natural Products and Bioprospecting, vol. 3, no. 5, pp. 207232, 2013. 
[2] K. Kathiresan and B. L. Bingham, "Biology of mangroves and mangrove ecosystems," Advances in Marine Biology, vol. 40, pp. 81-251, 2001.

[3] T. Ramanathan, A. Saranya, T. Ramanathan, K. S. Kesavanarayanan, and A. Adam, "Traditional medicinal uses, chemical constituents and biological activities of a mangrove plant, Acanthus ilicifolius Linn.: a brief review," Journal of Agriculture and Environmental Sciences, vol. 15, no. 2, pp. 243-250, 2015.

[4] M. A. Islam, M. Saifuzzaman, F. Ahmed et al., "Antinociceptive activity of methanolic extract of Acanthus ilicifolius linn. leaves," Turkish Journal of Pharmaceutical Sciences, vol. 9, no. 1, pp. 51-60, 2012.

[5] T. Chakraborty, D. Bhuniya, M. Chatterjee et al., "Acanthus ilicifolius plant extract prevents DNA alterations in a transplantable ehrlich ascites carcinoma-bearing murine model," World Journal of Gastroenterology, vol. 13, no. 48, p. 6538, 2007.

[6] B. H. Babu, B. S. Shylesh, and J. Padikkala, "Tumour reducing and anticarcinogenic activity of Acanthus ilicifolius in mice," Journal of Ethnopharmacology, vol. 79, no. 1, pp. 27-33, 2002.

[7] P. Van Kiem, T. H. Quang, T. T. Huong et al., "Chemical constituents of Acanthus ilicifolius L. and effect on osteoblastic MC3T3E1 cells," Archives of Pharmacal Research, vol. 31, no. 7, pp. 823-829, 2008.

[8] "Screening for antimicrobial activity in Acanthus ilicifolius," Archives of Applied Science Research, vol. 2, no. 5, pp. 311-315, 2010.

[9] R. Wöstmann and G. Liebezeit, "Chemical composition of the mangrove holly Acanthus ilicifolius (acanthaceae)-review and additional data," Senckenbergiana Maritima, vol. 38, no. 1, pp. 31-37, 2008.

[10] L. Liu, H. Fan, P. Qi et al., "Synthesis and hepatoprotective properties of Acanthus ilicifolius alkaloid A and its derivatives," Experimental and Therapeutic Medicine, vol. 6, no. 3, pp. 796-802, 2013.

[11] C. Subramani, A. Rajakkannu, A. Rathinam, S. Gaidhani, I. Raju, and D. V. Kartar Singh, "Anti-atherosclerotic activity of root bark of Premna integrifolia Linn. in high fat diet induced atherosclerosis model rats," Journal of Pharmaceutical Analysis, vol. 7, no. 2, pp. 123-128, 2017.

[12] T. A. Pearson, S. N. Blair, S. R. Daniels et al., "AHA guidelines for primary prevention of cardiovascular disease and stroke: 2002 update," Circulation, vol. 106, no. 3, pp. 388-391, 2002.

[13] P. Libby, P. M. Ridker, and A. Maseri, "Inflammation and atherosclerosis," Circulation, vol. 105, no. 9, pp. 1135-1143, 2002.

[14] L. F. Van Gaal, I. L. Mertens, and C. E. De Block, "Mechanisms linking obesity with cardiovascular disease," Nature, vol. 444, no. 7121, pp. 875-880, 2006.

[15] D. M. Hegsted, R. B. McGandy, M. L. Myers, and F. J. Stare, "Quantitative effects of dietary fat on serum cholesterol in man," The American Journal of Clinical Nutrition, vol. 17, no. 5, pp. 281-295, 1965.

[16] G. S. Getz and C. A. Reardon, "Diet and murine atherosclerosis," Arteriosclerosis, Thrombosis, and Vascular Biology, vol. 26, no. 2, pp. 242-249, 2006.

[17] G. Venkataiah, M. I. Ahmed, D. S. Reddy, and M. Rejeena, "Anti-diabetic activity of Acanthus ilicifolius root extract in alloxan induced diabetic rats," Indo American Journal of Pharmaceutical Research, vol. 3, no. 11, pp. 907-912, 2013.

[18] S. Mathew, "Flavonoids and phenolic compounds in two mangrove species and their antioxidant property," Indian Journal of Marine Sciences, vol. 41, no. 3, pp. 259-264, 2012.
[19] M. Firdaus, A. A. Prihanto, and R. Nurdiani, "Antioxidant and cytotoxic activity of Acanthus ilicifolius flower," Asian Pacific Journal of Tropical Biomedicine, vol. 3, no. 1, pp. 17-21, 2013.

[20] D. Avijit, R. Sarkar Md, S. Islam Howlader Md, H. Md, and M. Al-Hossain ASM, "Phytochemical screening and the evaluation of the antioxidant, cytotoxic and antimicrobial properties of Acanthus ilicifolius (family: acanthaceae)," International Research Journal of Pharmacy, vol. 3, no. 8, pp. 153-156, 2012.

[21] T. Paul and S. Ramasubbu, "The antioxidant, anticancer and anticoagulant activities of Acanthus ilicifolius L. roots and Lumnitzera racemosa willd. leaves, from southeast coast of India," Journal of Applied Pharmaceutical Science, vol. 7, no. 3, pp. 81-87, 2017.

[22] J. Wu, S. Zhang, J. Huang et al., "New aliphatic alcohol and (Z)-4-coumaric acid glycosides from Acanthus ilicifolius," Chemical and Pharmaceutical Bulletin, vol. 51, no. 10, pp. 1201-1203, 2003.

[23] J Wu, S Zhang, Q Xiao et al., "Megastigmane and flavone glycosides from Acanthus ilicifolius," Die Pharmazie, vol. 58, no. 5, pp. 363-364, 2003.

[24] T. Kanchanapoom, M. S. Kamel, R. Kasai, K. Yamasaki, C. Picheansoonthon, and Y. Hiraga, "Lignan glucosides from Acanthus ilicifolius," Phytochemistry, vol. 56, no. 4, pp. 369-372, 2001.

[25] C. Huo, H. Liang, G. Tu, Y. Zhao, and W. Lin, "A new 5, 11 epoxymegastigmane glucoside from Acanthus ilicifolius," Natural Product Research, vol. 22, no. 10, pp. 896-900, 2008.

[26] X. Han, T. Shen, and H. Lou, "Dietary polyphenols and their biological significance," International Journal of Molecular Sciences, vol. 8, no. 9, pp. 950-988, 2007.

[27] A. G. Báidez, P. Gómez, J. A. Del Río, and A. Ortuño, "Dysfunctionality of the xylem in olea Europaea L. plants associated with the infection process by verticillium dahliae Kleb. role of phenolic compounds in plant defense mechanism," Journal of Agricultural and Food Chemistry, vol. 55, no. 9, pp. 3373-3377, 2007.

[28] S. Veeriah, T. Kautenburger, N. Habermann et al., "Apple flavonoids inhibit growth of HT29 human colon cancer cells and modulate expression of genes involved in the biotransformation of xenobiotics," Molecular Carcinogenesis, vol. 45, no. 3, pp. 164-174, 2006.

[29] R. W. Owen, A. Giacosa, W. E. Hull, R. Haubner, B. Spiegelhalder, and H. Bartsch, "The antioxidant/anticancer potential of phenolic compounds isolated from olive oil," European Journal of Cancer, vol. 36, no. 10, pp. 1235-1247, 2000.

[30] Y.-J. Surh, "Cancer chemoprevention with dietary phytochemicals," Nature Reviews Cancer, vol. 3, no. 10, pp. 768-780, 2003.

[31] N. Sultana and A. Ata, "Oleanolic acid and related derivatives as medicinally important compounds," Journal of Enzyme Inhibition and Medicinal Chemistry, vol. 23, no. 6, pp. 739756, 2008.

[32] B. A. Shah, G. N. Qazi, and S. C. Taneja, "Boswellic acids: a group of medicinally important compounds," Natural Product Reports, vol. 26, no. 1, pp. 72-89, 2009.

[33] R. Gadekar, P. K. Singour, P. K. Chaurasiya, R. S. Pawar, and U. K. Patil, "A potential of some medicinal plants as an antiulcer agents," Pharmacognosy Reviews, vol. 4, no. 8, pp. 136-146, 2010. 
[34] J. B. Harborne, Phytochemical Methods : a Guide to Modern Techniques of Plant Analysis, Chapman and Hall, London, UK, 1998.

[35] A. Sofowora, Medicinal Plants and Traditional Medicine in Africa, Wiley, Hoboken, NJ, USA, 1982.

[36] A. A. Ghatak, P. A. Chaturvedi, and N. S. Desai, "Indian grape wines: a potential source of phenols, polyphenols, and antioxidants," International Journal of Food Properties, vol. 17, no. 4, pp. 818-828, 2014.

[37] J. L. Ble-Castillo, M. A. Aparicio-Trapala, I. E. Juárez-Rojop et al., "Differential effects of high-carbohydrate and high-fat diet composition on metabolic control and insulin resistance in normal rats," International Journal of Environmental Research and Public Health, vol. 9, no. 5, pp. 1663-1676, 2012.

[38] A. H. Lichtenstein, L. J. Appel, M. Brands et al., "Diet and lifestyle recommendations revision 2006," Circulation, vol. 114, no. 1, pp. 82-96, 2006.

[39] S. McGuire, "U.S. department of agriculture and U.S. department of health and human services, dietary guidelines for Americans, 2010. $7^{\text {th }}$ edition, Washington, DC, USA: U.S. government printing office, january 2011," Advances in Nutrition, vol. 2, no. 3, pp. 293-294, 2011.

[40] G. A. Bray, J. C. Lovejoy, S. R. Smith et al., "The influence of different fats and fatty acids on obesity, insulin resistance and inflammation," The Journal of Nutrition, vol. 132, no. 9, pp. 2488-2491, 2002.

[41] M. Rossmeisl, J. S. Rim, R. A. Koza, and L. P. Kozak, "Variation in type 2 diabetes-related traits in mouse strains susceptible to diet-induced obesity," Diabetes, vol. 52, no. 8 , pp. 1958-1966, 2003.

[42] D. Estadella, L. M. Oyama, A. R. Dâmaso, E. B. Ribeiro, and C. M. Oller Do Nascimento, "Effect of palatable hyperlipidic diet on lipid metabolism of sedentary and exercised rats," Nutrition, vol. 20, no. 2, pp. 218-224, 2004.

[43] H. Ratnawati and W. Widowati, "Anticholesterol activity of velvet bean (mucuna pruriens L.) towards hypercholesterolemic rats," Sains Malaysia, vol. 40, no. 4, pp. 317-321, 2011.

[44] S. L. Matos, H. D. Paula, M. L. Pedrosa et al., "Dietary models for inducing hypercholesterolemia in rats," Brazilian Archives of Biology and Technology, vol. 48, no. 2, pp. 203-209, 2005.

[45] S. Venkateshan, V. Subramaniyan, V. Chinnasamy, and S. Chandiran, "Anti-oxidant and anti-hyperlipidemic activity of Hemidesmus indicus in rats fed with high-fat diet," Avicenna Journal of Phytomedicine, vol. 6, no. 5, pp. 516-525, 2016.

[46] S. Bais, G. S. Singh, and R. Sharma, "Antiobesity and hypolipidemic activity of moringa oleifera leaves against high fat diet-induced obesity in rats," Advances in Biology, vol. 20149 pages, 2014.

[47] H. S. Cipil, A. Kosar, A. Kaya et al., "In vivo hemostatic effect of the medicinal plant extract ankaferd blood stopper in rats pretreated with Warfarin," Clinical and Applied Thrombosis/ Hemostasis, vol. 15, no. 3, pp. 270-276, 2009.

[48] S. Nishiyama, K. Nakamura, and Y. Konishi, "Blood pressure and urinary sodium and potassium excretion in cadmiumtreated male rats," Environmental Research, vol. 40, no. 2, pp. 357-364, 1986.

[49] F. C. Otuu, "Evaluation of oxidative stress-induced diabetic complications on alloxan-treated hyperglycaemic rats, using some biochemical parameters and histological profiles of three major organs," MOJ Toxicology, vol. 4, no. 2, 2018.

[50] N. W. Tietz, "Serum triglyceride determination," in Clinical Guide to Laboratory Tests, pp. 554-556, W.B. Saunders, Philadelphia, PA, USA, 1990.
[51] M. Burstein, H. R. Scholnick, and R. Morfin, "Rapid method for the isolation of lipoproteins from human serum by precipitation with polyanions," Journal of Lipid Research, vol. 11, no. 6, pp. 583-595, 1970.

[52] W. T. Friedewald, R. I. Levy, and D. S. Fredrickson, "Estimation of the concentration of low-density lipoprotein cholesterol in plasma, without use of the preparative ultracentrifuge," Clinical Chemistry, vol. 18, no. 6, pp. 499-502, 1972.

[53] A. Onat, G. Can, H. Kaya, and G. Hergenç, “" Atherogenic index of plasma" (log10 triglyceride/high-density lipoprotein-cholesterol) predicts high blood pressure, diabetes, and vascular events," Journal of Clinical Lipidology, vol. 4, no. 2, pp. 89-98, 2010.

[54] Y. Li and N. Wang, "Antithrombotic effects of Danggui, Honghua and potential drug interaction with clopidogrel," Journal of Ethnopharmacology, vol. 128, no. 3, pp. 623-628, 2010.

[55] H. Chen, M. Jin, Y.-F. Wang et al., "Effect of toona microcarpa harms leaf extract on the coagulation system," BioMed Research International, vol. 2014, 2014.

[56] Y. Kong, J.-L. Huo, W. Xu, J. Xiong, Y.-M. Li, and W.-T. Wu, "A novel anti-platelet aggregation tripeptide from Agkistrodon acutus venom: isolation and characterization," Toxicon, vol. 54, no. 2, pp. 103-109, 2009.

[57] L. Xinyan, H. Guozhu, Z. Suwen et al., "Effects of Veratrum nigrum var. ussuriense alkaloids on platelet aggregation and time of coagulation and bleeding," Chinese Traditional and Herbal Drugs, vol. 35, no. 11, Article ID 12691272, 2004.

[58] G. Gong, Y. Qin, and W. Huang, "Anti-thrombosis effect of diosgenin extract from Dioscorea zingiberensis C.H. Wright in vitro and in vivo," Phytomedicine, vol. 18, no. 6, pp. 458-463, 2011.

[59] M. Kogushi, T. Matsuoka, T. Kawata et al., "The novel and orally active thrombin receptor antagonist E5555 (Atopaxar) inhibits arterial thrombosis without affecting bleeding time in Guinea pigs," European Journal of Pharmacology, vol. 657, no. 1-3, pp. 131-137, 2011.

[60] M. N. Kabidul Azam, M. M. Rahman, S. Biswas, and M. N. Ahmed, "Appraisals of Bangladeshi medicinal plants used by folk medicine practitioners in the prevention and management of malignant neoplastic diseases," International Scholarly Research Notices, vol. 2016, Article ID 7832120, 2016.

[61] P. K. Sardar, S. Dev, M. A. Al Bari et al., "Antiallergic, anthelmintic and cytotoxic potentials of dried aerial parts of Acanthus ilicifolius L.," Clinical Phytoscience, vol. 4, no. 1, pp. 1-13, 2018.

[62] Y. Gavamukulya, F. Abou-Elella, F. Wamunyokoli, and H. AEl-Shemy, "Phytochemical screening, anti-oxidant activity and in vitro anticancer potential of ethanolic and water leaves extracts of Annona muricata (Graviola)," Asian Pacific Journal of Tropical Medicine, vol. 7, no. S1, pp. S355-S363, 2014.

[63] A. Luximon-Ramma, T. Bahorun, M. A. Soobrattee, and O. I. Aruoma, "Antioxidant activities of phenolic, proanthocyanidin, and flavonoid components in extracts of Cassia fistula," Journal of Agricultural and Food Chemistry, vol. 50, no. 18, pp. 5042-5047, 2002.

[64] J. Spavieri, A. Allmendinger, M. Kaiser et al., "Antimycobacterial, antiprotozoal and cytotoxic potential of twenty-one brown algae (phaeophyceae) from British and Irish waters," Phytotherapy Research, vol. 24, no. 11, pp. 1724-1729, 2010. 
[65] G. A. Gayathri, G. Mahalingam, and R. Nathiya, "Quantitative phytochemical analysis, in vitro reducing power and antioxidant activity of methanol leaf extract of Acanthus ilicifolius," International Journal of Pharmacognosy and Phytochemical Research, vol. 7, no. 1, 2014.

[66] G. A. Gayathri, "Preliminary qualitative phytochemical screening and in vitro hypoglycemic potential of Acanthus ilicifolius and evolvulus emerginatus," International Journal of Pharmacy and Pharmaceutical Sciences, vol. 6, no. 6, pp. 362-365, 2014.

[67] D. Banerjee, S. Chakrabarti, A. K. Hazra et al., "Antioxidant activity and total phenolics of some mangroves in Sundarbans," African Journal of. Biotechnology, vol. 7, no. 6, pp. 805-810, 2008.

[68] S. Mukherjee, N. Pawar, O. Kulkarni et al., "Evaluation of freeradical quenching properties of standard Ayurvedic formulation Vayasthapana Rasayana," BMC Complementary and Alternative Medicine, vol. 11, p. 38, 2011.

[69] M. F. Nielsen and K. U. Ingold, "Kinetic solvent effects on proton and hydrogen atom transfers from phenols. similarities and differences," Journal of the American Chemical Society, vol. 128, no. 4, pp. 1172-1182, 2006.

[70] F. Breton, S. Cérantola, and E. Ar Gall, "Distribution and radical scavenging activity of phenols in Ascophyllum nodosum (Phaeophyceae)," Journal of Experimental Marine Biology and Ecology, vol. 399, no. 2, pp. 167-172, 2011.

[71] R. Bora, P. P. Adhikari, A. K. Das, N. Raaman, and G. D. Sharma, "Ethnomedicinal, phytochemical, and pharmacological aspects of genus Acanthus," International Journal of Pharmacy and Pharmaceutical Sciences, vol. 9, no. 12, p. 18, 2017.

[72] R. Biswas, S. M. M. Rahman, K. M. Didarul Islam et al., "Antioxidant, anti-inflammatory, and anticoagulation properties of Aegiceras corniculatum and Acanthus ilicifolius," Pharmaceutical and Biomedical Research, vol. 5, no. 3, 2019.

[73] A. P. Kourounakis, D. Galanakis, K. Tsiakitzis, E. A. Rekka, and P. N. Kourounakis, "Synthesis and pharmacological evaluation of novel derivatives of anti-inflammatory drugs with increased antioxidant and anti-inflammatory activities," Drug Development Research, vol. 47, no. 1, pp. 9-16, 1999.

[74] D. Zheleva-Dimitrova, P. Nedialkov, and G. Kitanov, "Radical scavenging and antioxidant activities of methanolic extracts from hypericumspecies growing in Bulgaria," Pharmacognosy Magazine, vol. 6, no. 22, pp. 74-78, 2010.

[75] S. Ostrovidov, P. Franck, D. Joseph et al., "Screening of new antioxidant molecules using flow cytometry," Journal of Medicinal Chemistry, vol. 43, no. 9, pp. 1762-1769, 2000.

[76] "The lipid research clinics coronary primary prevention trial results: I. reduction in incidence of coronary heart disease," JAMA: The Journal of the American Medical Association, vol. 251, no. 3, pp. 351-364, 1984.

[77] N. Mn and A. My, "Beneficial lipid-lowering effects of pink guava puree in high fat diet induced-obese rats," Malaysian Journal of Nutrition, vol. 16, no. 1, pp. 171-185, 2010.

[78] A. S. Koshy, L. Anila, and N. R. Vijayalakshmi, "Flavonoids from Garcinia cambogia lower lipid levels in hypercholesterolemic rats," Food Chemistry, vol. 72, no. 3, pp. 289-294, 2001.

[79] P. O. Kwiterovich, "The effect of dietary fat, antioxidants, and pro-oxidants on blood lipids, lipoproteins, and atherosclerosis," Journal of the American Dietetic Association, vol. 97, no. 7, pp. S31-S41, 1997.
[80] G. Assmann and A. M. Gotto, "HDL cholesterol and protective factors in atherosclerosis," Circulation, vol. 109, no. 23_suppl_1, pp. 3-8, 2004.

[81] J. Kim and S. Amar, "Periodontal disease and systemic conditions: a bidirectional relationship," Odontology, vol. 94, no. 1, pp. 10-21, 2006.

[82] V. Pamidiboina, R. Razdan, and M. G. Hariprasad, "Evaluation of the antihyperlipidemic, cardioprotective activity of a polyherbal formulation," nternational Journal of Pharmacy and Pharmaceutical Sciences, vol. 2, no. 1, pp. 86-91, 2010.

[83] G. A. Otunola, O. B. Oloyede, A. T. Oladiji, and A. A. Afolayan, "Effects of diet-induced hypercholesterolemia on the lipid profile and some enzyme activities in female Wistar rats," African Journal of. Biochemistry Research, vol. 4, no. 6, pp. 149-154, 2010.

[84] T. Goto, N. Takahashi, S. Hirai, and T. Kawada, "Various terpenoids derived from herbal and dietary plants function as PPAR modulators and regulate carbohydrate and lipid metabolism," PPAR Research, vol. 2010, p. 9, 2010.

[85] S. Salvamani, B. Gunasekaran, N. A. Shaharuddin, S. A. Ahmad, and M. Y. Shukor, "Antiartherosclerotic effects of plant flavonoids," Biomed Research International, vol. 2014, Article ID 480258, 2014.

[86] K. Zeka, K. Ruparelia, R. Arroo, R. Budriesi, and M. Micucci, "Flavonoids and their metabolites: prevention in cardiovascular diseases and diabetes," Diseases, vol. 5, no. 3, p. 19, 2017.

[87] C. L. Millar, Q. Duclos, and C. N. Blesso, "Effects of dietary flavonoids on reverse cholesterol transport, HDL metabolism, and HDL function," Advances in Nutrition: an International Review Journal, vol. 8, no. 2, pp. 226-239, 2017.

[88] A. L. B. Zeni, T. D. Moreira, A. P. Dalmagro et al., "Evaluation of phenolic compounds and lipid-lowering effect of Morus nigra leaves extract," Anais Da Academia Brasileira De Ciências, vol. 89, no. 4, pp. 2805-2815, 2017.

[89] "Evaluation of phytochemical properties and diuretic activity of ethanolic extract of Acanthus ilicifolius linn in wistar rats," International Journal of Advances in Pharmaceutical Sciences, vol. 4, no. 8, pp. 2056-2060, 2013.

[90] B. Lassègue and K. K. Griendling, "Reactive oxygen species in hypertension * 1 an update," American Journal of Hypertension, vol. 17, no. 9, pp. 852-860, 2004.

[91] T. Paravicini and R. Touyz, "Redox signaling in hypertension," Cardiovascular Research, vol. 71, no. 2, pp. 247-258, 2006.

[92] R. Rodrigo, R. Brito, and J. González, "Oxidative stress and essential hypertension," in Update on Essential HypertensionInTech, London, UK, 2016.

[93] D. Procházková and N. Wilhelmová, "Leaf senescence and activities of the antioxidant enzymes," Biologia Plantarum, vol. 51, no. 3, pp. 401-406, 2007.

[94] R. B. Singh, S. S. Rastogi, R. Singh, S. Ghosh, and M. A. Niaz, "Effects of guava intake on serum total and high-density lipoprotein cholesterol levels and on systemic blood pressure," The American Journal of Cardiology, vol. 70, no. 15, pp. 1287-1291, 1992.

[95] Z. H. Ahmed, "Antioxidant and anticoagulation activities of flavonoid glycoside group extracted from ginger," Al-Qadisiyah Journal of Pure Science, vol. 4, no. 21, 2016.

[96] P. K. Tiwari, M. Kaur, and H. Kaur, "Phytochemical screening and extraction: a review," Internationale Pharmaceutica Sciencia, vol. 1, no. 1, pp. 96-106, 2011. 